\title{
A VEZETŐI MAGATARTÁS HATÁSA A TELJESÍTMÉNYJAVULÁSRA A FELDOLGOZÓIPARBAN A LEAN TERMELÉSI TECHNIKÁK MEDIÁLÓ HATÁSA
}

Az értékekkel, attitűdökkel, vezetői stílusokkal és vezetési jegyekkel kapcsolatos empirikus vizsgálatok egyre nagyobb teret nyernek a lean környezetben tevékeny vezetőkkel foglalkozó kutatásokban. A szerzők empirikus munkája a GLOBEkutatás változóinak egy szűkített, 29 tételes halmazára építve vizsgálja, hogyan mediálják a lean technikák a vezetési jegyek teljesítményjavulásra gyakorolt hatását. Eredményeik szerint az ügyvezetőket és a termelésvezetőket a hazai 50 főnél nagyobb feldolgozóipari cégek mintáján a fejlődésorientált, az autokratikus, a formális, a mikromenedzser és a motiváló vezetői magatartás jellemzi. Kutatásuk mindkét vezetői pozícióban rávilágít a fejlődésorientált és az autokrata magatartások lean termelési technikák használatára gyakorolt pozitív hatására. A lean technikák mediáló hatásánál eltérő az észlelés: az ügyvezetők szerint a lean technikák mediáló hatása jelen van, míg a termelésvezetők szerint a teljesítményjavulás mögött a vezetési magatartások állnak. ${ }^{1}$

\section{Kulcsszavak: lean menedzsment, vezetési jegyek, feldolgozóipar, teljesítményjavulás}

A feldolgozóipari vállalatok versenyképességének javítását számos különböző program támogatta az elmúlt évtizedekben. Az 1980-as és 1990-es években a teljes körü minőségmenedzsmentnek (Total Quality Management, TQM) (Berényi, 2017; Topár, 2009) volt a legnagyobb hatása. A 2000-es évektől a több menedzsmentinnovációt integráló (pl. just-in-time, TQM, agile) (Hines - Holweg Rich, 2004; Kovács Z., 2004) lean termelés térnyerésének vagyunk tanúi (Holweg, 2007; Womack - Jones, 1996). A leannel kapcsolatban a gyakorlati és az akadémiai érdeklődés máig döntően technikai szemléletü (Netland, 2013). Ez arra utal, hogy az érdeklődés középpontjában a lean gyakorlat csomag eszközeinek meghatározása és leírása, azok rendszerbe foglalása (Liker, 2004; Shah - Ward, 2007; Shah - Ward, 2003; Womack - Jones, 1996), továbbá ezen eszközök és a teljesítménymutatók közötti kapcsolatok bizonyítása (Demeter - Matyusz, 2011; Demeter - Losonci, 2013; Losonci - Borsos, 2015) áll.

Egy új szemlélet megjelenésére utal, hogy a 2010es évektől a lean rendszer sikere szempontjából kritikus vezetéstudományi témákra is egyre komolyabb figyelem irányul. Ezen empirikus munkák eltérő leadership koncepciókat (pl. érték, magatartás, jegy, stílus) vizsgálnak, különbözően gondolkodnak a lean és leadership koncepció kapcsolatáról (melyik hat melyikre). Néhány kivételtől eltekintve nem foglalkoznak a leadership és a teljesítmény kapcsolatával sem (Zarinah - Farhana - Nadiah, 2017; Seidel - Saurin - Marodin - Ribeiro, 2017). Empirikus munkánk egyszerre integrál több, eddig kevés figyelmet kapó irányt: a GLOBE (Global Leadership - Organisational Behavior Effectiveness) projektből (Hanges - Dickson, 2004) adaptált vezetési jegyek teljesítményjavulásra gyakorolt hatására vizsgáljuk meg a lean termelési rendszer gyakorlatainak mediáló hatását két vezetői szinten (termelésvezetö, ügyvezető).

A téma kutatását ösztönzi, hogy a lean menedzsmentet széles körben használó ágazatok (pl. autóipar, elektronika) idehaza is nagy és egyre nagyobb gazdasági jelentőségűek. Ezen ágazatok az autóipari összeszerelőkön (pl. Nyugat-Dunántúl, Közép-Dunántúl, Alföld) és beszállítókon keresztül területileg az egész országban jelen vannak, több megye gazdaságában akár „kritikus” koncentrációt mutatva.

A cikk felépítése az alábbi logikát követi. A lean termelési rendszer bemutatása után röviden tárgyalja a leadership fogalmát, majd a lean irodalomban megjelenő leadership koncepciókkal kapcsolatos eredményeket szintetizálja. Ezen irodalmi rész végén fogalmazza meg a kutatás hipotézisét. Az adatbázis és a minta bemutatását követik a módszertani megfontolások, ide értve az operacionalizálás kérdéseit is. Az eredmények után azok értelmezése, a konklúzió és menedzsereknek szóló javaslatok következnek. A munkát a további kutatási lehetőségek és a korlátok számbavétele zárja.

\section{Szakirodalmi áttekintés \\ A lean termelési rendszer - elmélet és gyakorlat}

A lean termelési rendszert a Toyota termelési rendszeréből (Toyota Production System, TPS) származtathatjuk (Ohno, 1988). Liker 14 alapelvet megfogalmazva a TPS szerkezetének négy szintjét különbözteti meg: a filozófiát (1. alapelv), a folyamatokat (2-8. alapelv), a munkatársakat és partnereket (9-11. alapelv) és a problémamegoldást (1214. alapelv) (Liker, 2004). Meglátása szerint a Toyota mind a négy szinten sajátos rutinokat müködtet. A szerző arra is felhívja a figyelmet, hogy bár a gyakorlati élet leginkább a - látható - folyamatszervezéssel kapcsolatos megfon-

\footnotetext{
${ }^{1}$ A publikáció a Széchenyi 2020 program EFOP- HYPERLINK "callto:3.6.1-16-2016-00013" 3.6.1-16-2016-00013 "Intelligens szakosodást szolgáló intézményi fejlesztések a Budapesti Corvinus Egyetem székesfehérvári Campusán" címủ Európai Uniós projektje keretében készült.
} 
tolásokat igyekszik átvenni, valamennyi szint adaptálása szükséges egy fenntartható lean rendszer kialakításához.

Nemzetközi vállalatok formális termelési rendszereinek vizsgálata (Netland, 2013), illetve az idehaza müködő lean vállalatok által használt eszközök hatásainak elemzése is megerősíti (Kovács - Rendesi, 2015), hogy a lean rendszer vállalati adaptálása „féloldalas”. A látható folyamatszervezési technikák kerülnek be leggyakrabban a termelési rendszerekbe, pl. értékáram, húzásos rendszer, standard munka (Netland, 2013). A hazai tapasztalatok is azt mutatják, hogy a feldolgozóipari cégek nagyobb részénél nem vagy alig történik szervezeti változás a leanhez kapcsolódóan, illetve sokan a célrendszer módosításában sem tesznek lépéseket (Kovács - Rendesi, 2015). Ezek alapján elmondható, hogy a cégek a lean rendszer technikai szemléletében gondolkodnak.

\section{Leadership - nemzetközi és hazai eredmények}

Kutatásunkban - Gelei, Losonci, Toarniczky és Báthory (2013), valamint Gelei, Losonci és Matyusz (2015) lean és leadership közötti kapcsolatot vizsgáló munkáival összhangban - a kontingencialista leadership megközelítést követjük. Feltételezzük, hogy a lean termelési kontextusban meghatározó bizonyos vezetési magatartás és stílus hatása.

A vezetési magatartás megragadására az egyik legnagyobb hatású és legátfogóbb nemzetközi összehasonlító leadership vizsgálat, a GLOBE kutatás kínál lehetőséget. E választásunkat nemcsak a GLOBE kutatás lean kontextusban való korábbi hazai használata, hanem a hazai menedzsmentkutatásokban betöltött hosszú és meghatározó szerepe is erősíti (Bakacsi - Takács, 1998; Karácsonyi, 2006; Bakacsi - Sarkadi-Nagy, 2003; Bauer, 2013).

A GLOBE kutatás 112 vezetési jegy változóra tesz javaslatot. Ebből a 112 jegyből (Hanges - Dickson, 2004) a nemzetközi eredmények alapján 74 változót sorol be 21 elsődleges és 6 másodlagos leadership faktorba (skálára). A másodlagos skála hat eleme a karizmatikus, a csoportorientált, az énközpontúság, a részvételi, a humánorientált és az autonóm neveket kapta.

A magyar elemzések mind a jegyek szintjén, mind a faktoroknál kicsi átfedést mutatnak e nemzetközi eredménnyel. Számos, e nemzetközi forrásba be sem kerülő változó ad sajátos karaktert a magyar eredményeknek. Bakacsi és Takács (1998) a kiskirály, a hiteles-participatív, a változásvezető, a remete és bürokrata implicit leadership faktorokat különböztette meg. Karácsonyi (2006) a Hanges és Dickson (2004) által használt elsődleges és másodlagos skálákhoz 95 változót rendel hozzá, amelyek alapján a vízionárius-mozgató, a diktátor, a hiteles-fejlesztő, a megbízható, a tiltakozó, a kívülálló és a kézivezérlő implicit leadership elméleteket határozza meg. Karácsonyi is megjegyzi - és az 1. melléklet is szemléletesen mutatja -, hogy a két eltérö időpontban és eltérő mintán végzett magyar kutatás eredményei között szintén kicsi az átfedés. Bakacsi és Sarkadi-Nagy (2003) ugyanakkor - a magyar minta eltérö eredményei mellett is - azt hangsúlyozza, hogy a magyar leadership nemzetközi kontextusba helyezve Európa latin országaival (pl. spanyol, portugál, olasz) mutat hasonlóságot.

\section{Leadership koncepciók vizsgálata lean kontextusban}

Jól szemlélteti a vezetők iránt fokozódó érdeklődést a leannel foglalkozók körében, hogy a gyakorlati életben nagy hatású bestseller sorozat szerzője, Jeffrey K. Liker 2004-ben még a lean (Toyota) termelési rendszer 14 alapelvéröl írt munkája (Liker, 2004), 2008-ban már a lean kultúrával (Liker - Hoseus, 2008) foglalkozik, 2012-ben pedig a lean leadership (Liker - Convis, 2012) témakörét járja körül. Liker meglátása szerint a Toyota a lean termelési rendszert és a lean leadership rendszert egyszerre alkotta meg, és míg előbbiről már sokat tudunk, addig utóbbi mostanáig kevés figyelmet kapott. Az aktuálisan kiemelt figyelem mellett a vezetők lean rendszerbe történő mély beágyazottságát jól illusztrálja Gelei, Losonci, Toarniczky és Báthory (2013) munkája. A szerzők Liker, TPS-t leíró 14 alapelve szerint osztályozták, hogy adott alapelv mennyiben kapcsolódhat közvetlenül a vezetőhöz és a vezetési jegyekhez. Meglátásuk szerint a 14 alapelvből 6 kapcsolódik a vezetőkhöz. Ez a hat alapelv a TPS mind a négy szintjét érinti.

A 2010-es évek elejétől jelennek meg a nemzetközi és a hazai szakirodalomban empirikus kutatások (1. táblázat). E kutatásokban a vizsgált leadership koncepció, a fókusz, a lean és a leadership közötti hatás iránya, a vezetői szint, valamint a módszertan is nagyon szerteágazó. A földrajzi régióban dominálnak az európai országok, mellettük délamerikai és ázsiai eredmények érhetők el.

A kutatásokban előkerülő leadership koncepció kialakításának egyik érvényes megközelítése, hogy az elérhető lean termeléssel foglalkozó irodalmakból vezetnek le a szerzők értékeket (van Dun - Hicks - Wilderom, 2017) és kompetencialistákat (Camuffo - Gerli, 2012; Seidel - Saurin - Marodin - Ribeiro, 2017). A másik, az empirikus munkákban szélesebb körben teret nyert megközelítés, hogy a kutatás korábban már használt leadership koncepciókra épít. Így az értékek (van Dun - Wilderom, 2016), a vezetési jegyek (Gelei - Losonci - Matyusz, 2015) és a különféle vezetési stílusok is helyet kapnak (Tortorella Fogliatto, 2017; Zarinah - Farhana - Nadiah, 2017).

A sokféle leadership koncepciót nagyon eltérő fókuszszal elemezzük. A kutatások egy része azt mutatja be, hogy lean kontextusban milyen a leadership (van Dun - Hicks - Wilderom, 2017; Camuffo - Gerli, 2012), a lean érettségével miként változik a vezetői stílus (Tortorella -Fettermann - Anzanello - Sawhney, 2017), illetve érett lean szervezetben milyen vezető-utánpótlás jellemző (Spear, 2004). Ezek a munkák nem tárgyalják expliciten a hatások irányát a két téma között - bár azt lehet sejteni, hogy a lean hatására történik változás. Számos munka arra a feltételezésre

\footnotetext{
${ }^{1}$ A tanulmány elején jeleztük, hogy a lean rendszer nagyrészt integrálta a TQM-elveket, -elemeket. A vezetési stílust és a szervezeti kultúrát TQM-kontextusban vizsgáló munkák döntően arra a feltételezésre épülnek, hogy a vezetési stílus és a szervezeti kultúra határozza meg a TQM adaptálását (Beer, 2003; Laohavichien - Fredendall - Cantrell, 2011)
} 


\begin{tabular}{|c|c|c|c|c|c|c|c|}
\hline 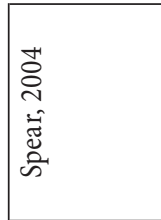 & 点 & 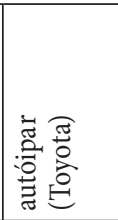 & 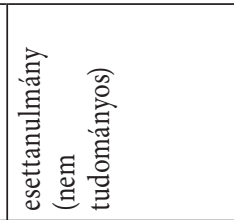 & 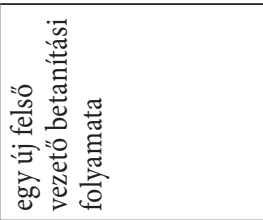 & . & 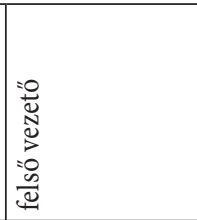 & . \\
\hline 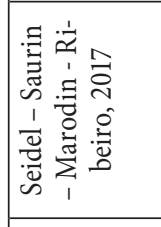 & 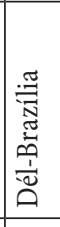 & 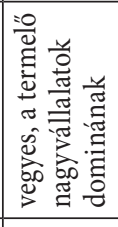 & 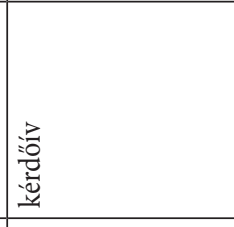 & 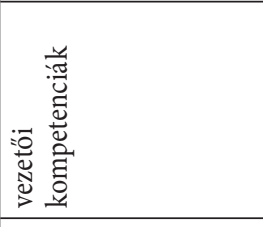 & 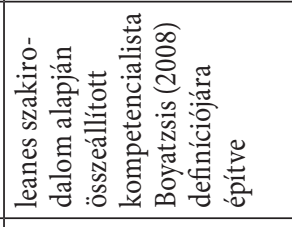 & 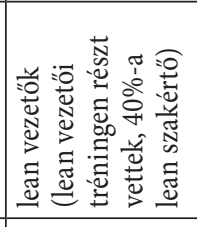 & 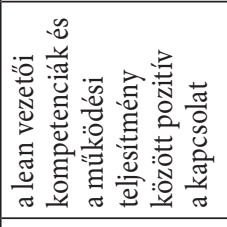 \\
\hline 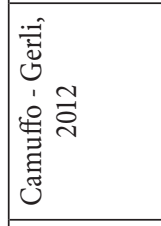 & 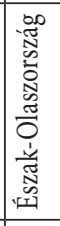 & 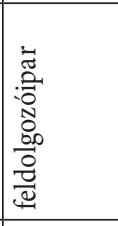 & 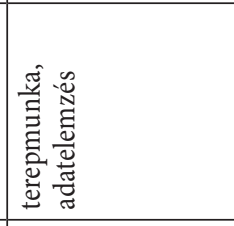 & 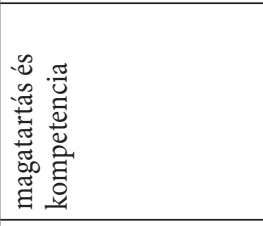 & 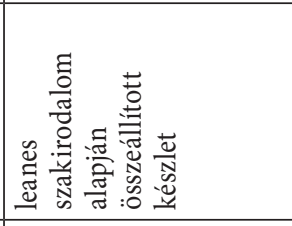 & 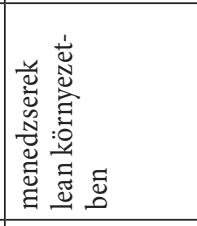 & . \\
\hline 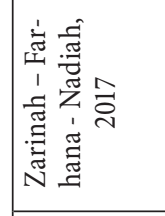 & 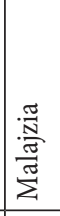 & 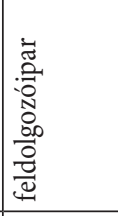 & 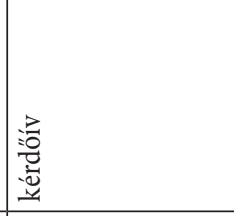 & 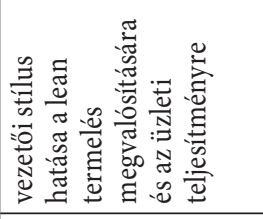 & 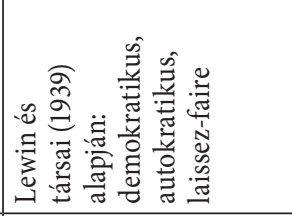 & 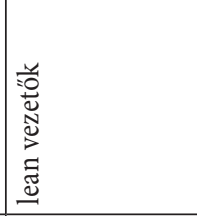 & 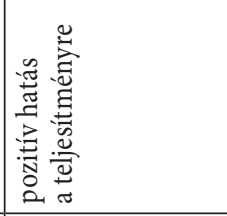 \\
\hline 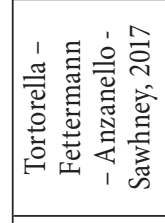 & 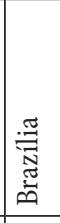 & 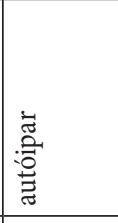 & 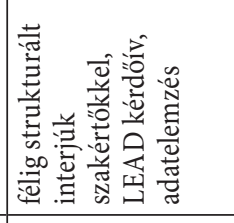 & 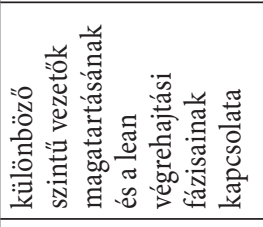 & 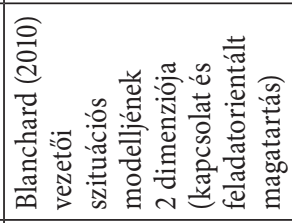 & 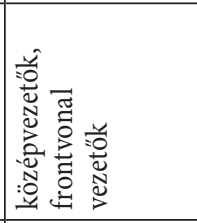 &. \\
\hline 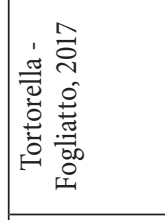 & 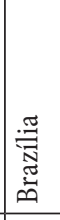 & 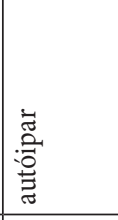 & 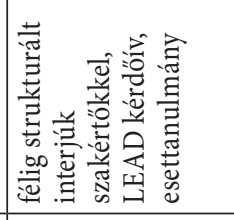 & 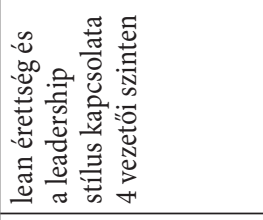 & 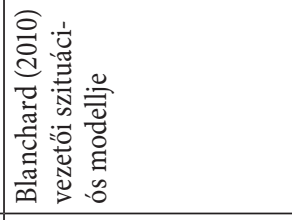 & 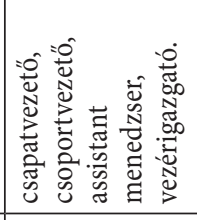 & \\
\hline 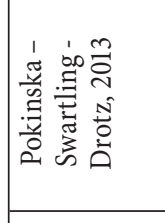 & 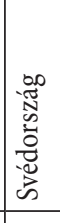 & 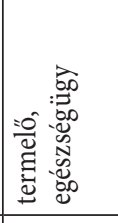 & 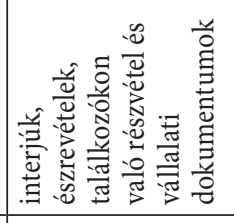 & 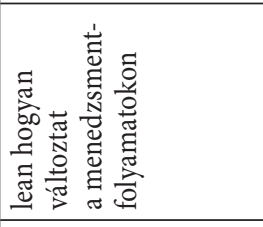 & (1. & 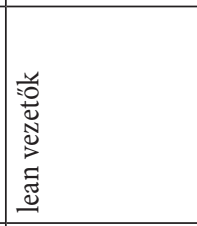 & . \\
\hline 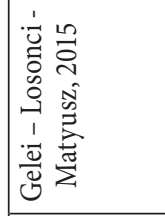 & 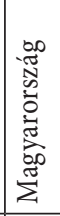 & 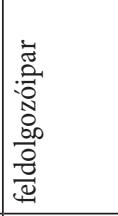 & 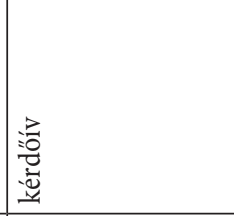 & 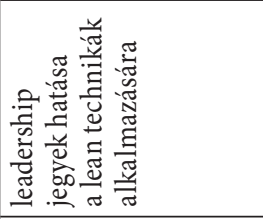 & 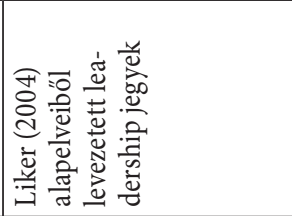 & 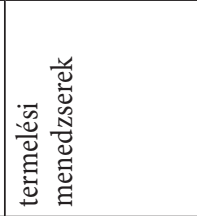 & , \\
\hline 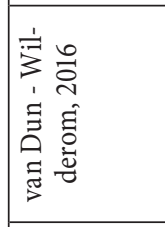 & 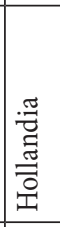 & 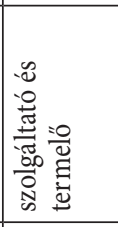 & 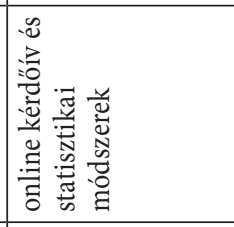 & 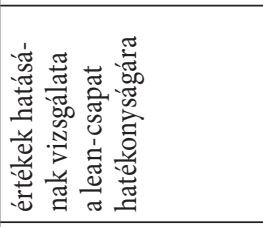 & 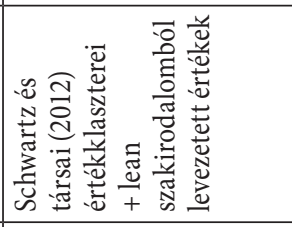 & 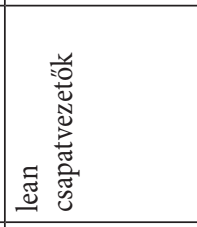 & I \\
\hline 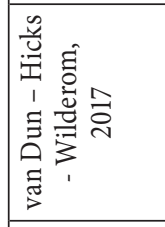 & 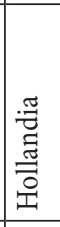 & 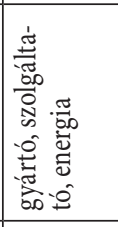 & 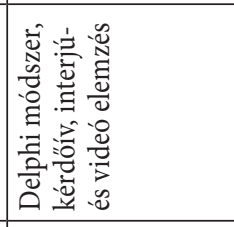 & 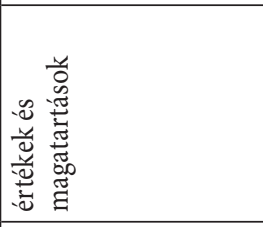 & 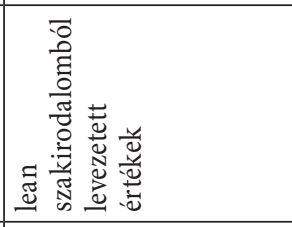 & 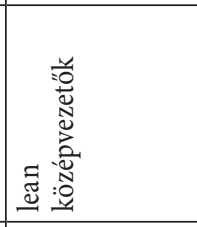 & \\
\hline & 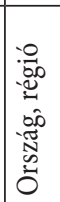 & \begin{tabular}{|l} 
苍 \\
总 \\
S.
\end{tabular} & 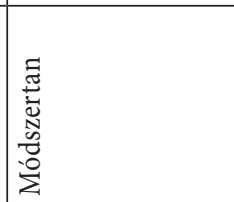 & 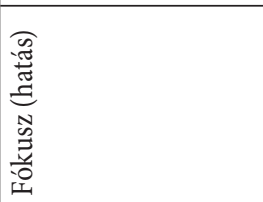 & 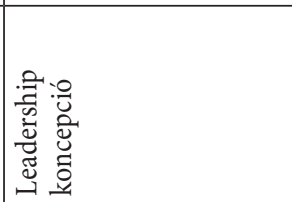 & 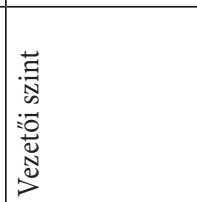 & 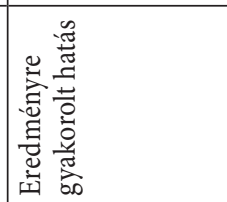 \\
\hline
\end{tabular}

1. táblázat Leadership koncepciók a lean termeléssel foglalkozó irodalomban - áttekintés 


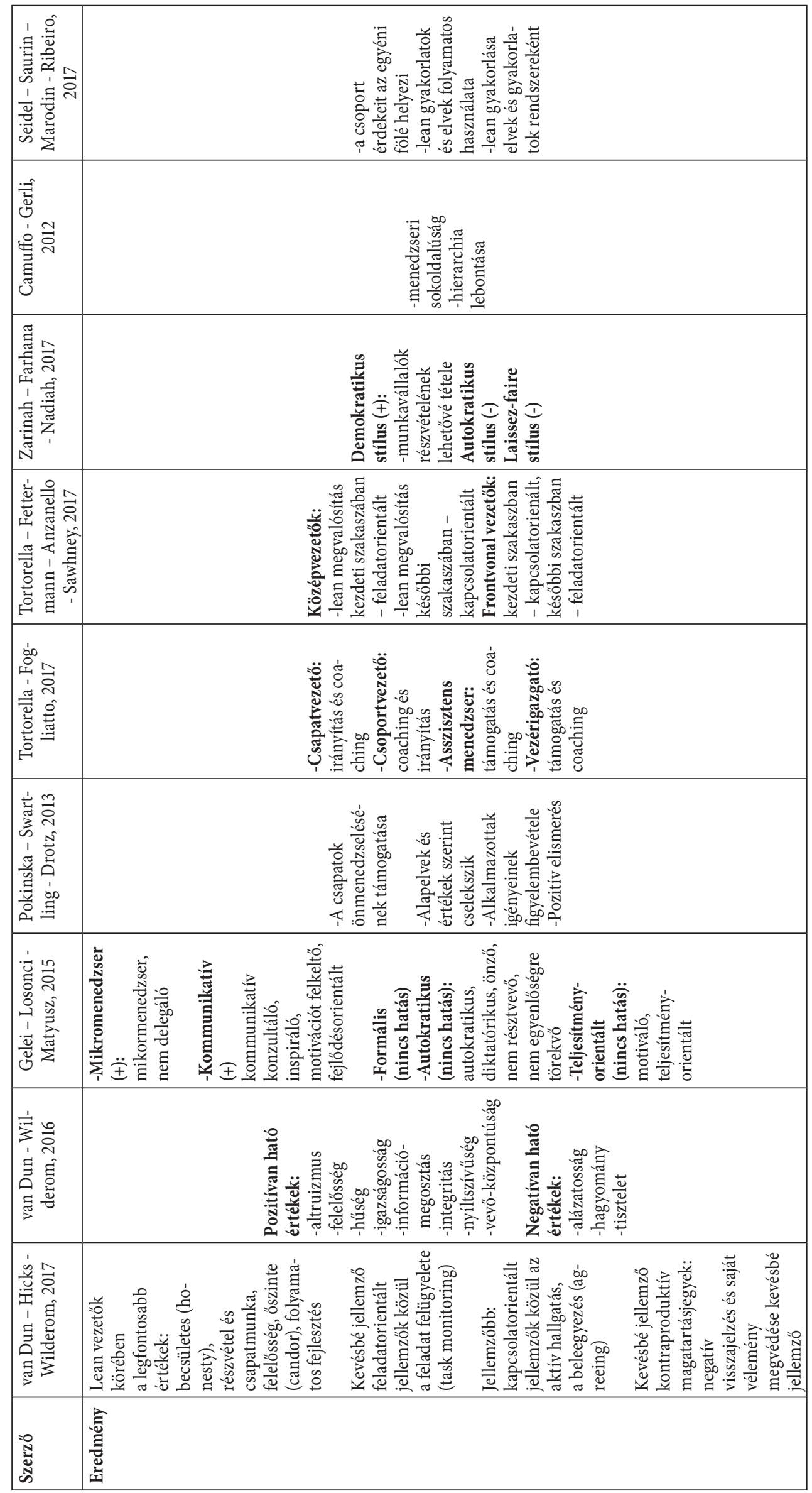

épít, hogy a vezetés, az értékek alakítják a leant (van Dun-

Hicks - Wilderom, 2017; Gelei - Losonci - Matyusz, 2015). ${ }^{1}$ 2. táblázat Leadership koncepciók a lean termeléssel foglalkozó irodalomban - eredmények 
Olyan megközelítés is van, amely explicit a lean hatásából vezet le változásokat (Pokinska - Swartling - Drotz, 2013).

Bár számos munka a lean vezetőkkel foglalkozik, e szervezeti szinttől lefelé és felfelé is van elmozdulás, sokszor túllépve akár a leanért felelős szervezeti osztály határán is. Az egyes hierarchiaszinteken észlelt stílus összevetésére azonban csak Tortorella és Fogliatto (2017), illetve Tortorella, Fettermann, Anzanello és Sawhney (2017) vállalkozott.

Meglátásuk szerint az egyes vezetői szinteken tapasztalt (hatékony) vezetési stílusok markánsan eltérnek egymástól és adott szinten a lean érettség szakaszától függően is változik a vezetési stílus.

Végül, bár a lean szakirodalom egyik meghatározó vonása, hogy a lean és a teljesítmény közötti kapcsolatot helyezi elötérbe, e kutatások között csak Zarinah, Farhana és Nadiah (2017), illetve Seidel, Saurin, Marodin és Ribeiro (2017) foglalkoznak e kérdéskörrel. Az első kutatócsoport szerint a lean termelés és a demokratikus vezetői stílus pozitívan hatnak a teljesítményre, míg az utóbbiaknál szignifikáns a lean leadership kompetencia és a működési teljesítmény közötti kapcsolat. Erős korlátai e kutatásoknak, hogy Zarinah, Farhana és Nadiah (2017) munkájában a felhasznált változók köre nem ismerhető meg, míg Seidel, Saurin, Marodin és Ribeiro (2017) csak a kapcsolat meglétére fókuszál (asszociációs együtthatókat használtak).

A lean környezetet jellemző magatartással, értékkel vagy stílussal kapcsolatos állásfoglalást megnehezíti az alkalmazott koncepciók sokfélesége (2. táblázat). Az biztosan állítható, hogy a kutatások differenciálnak: ráirányítják a figyelmet arra, hogy a lean használatának szempontjából a pozitívan ható és a negatívan ható tényezők mellett semleges jellemzők is vannak. Bár csak néhány párba állított kutatás alapján jelenthető ki, de a lean szervezetekben a vezetőre jellemző a résztvevő (van Dun - Hicks - Wilderom, 2017; Zarinah - Farhana - Nadiah, 2017) és a kapcsolatorientált (van Dun - Hicks - Wilderom, 2017; Tortorella - Fettermann - Anzanello - Sawhney, 2017) értékek, továbbá az altruista és önzetlen (van Dun - Hicks - Wilderom, 2017; Seidel - Saurin - Marodin - Ribeiro, 2017) magatartás. Ezeken túlmenően a kutatások egyenként hívják fel a figyelmet a kommunikatív magatartás (Gelei - Losonci - Matyusz, 2015), a demokratikus stílus (Zarinah - Farhana - Nadiah, 2017) és számos további érték pozitív hatására (pl. felelősség, altruizmus, hűség, igazságosság) (van Dun - Hicks - Wilderom, 2017).

A negatív hatással bíró jellemzők megítélése ellentmondásos. Zarinah, Farhana és Nadiah (2017) az autokratikus vezetői stílussal és a nem résztvevőként jellemezhetô laissez-faire stílussal kapcsolatban is a leanre gyakorolt negatív hatást emelik ki. Gelei, Losonci és Matyusz (2015) kutatásában e stílusokhoz hasonló tartalommal megjelenő autokratikus magatartásnak nincsen kapcsolata a leannel. Söt, Gelei, Losonci és Matyusz (2015) kutatásukban a nem delegáló jeggyel bíró mikrovezetőt - bár lehet, hogy csak a sajátos magyar vezetési stílus okán, de egy - a lean gyakorlatok használatára pozitívan ható magatartásként határozzák meg. Eközben például van Dun és Wilderom
(2016) eredményei nincsenek átfedésben ezen ellentmondó megállapításokkal. Ök lean környezetben az alázatosság, a hagyomány és a tisztelet negatív hatásaira hívják fel a figyelmet.

Sajnálatos, hogy a semleges hatású tényezők számbavétele esetleges. Gelei, Losonci és Matyusz (2015) eredményei élesen rávilágítanak, hogy például a lean kontextussal jól rezonáló motiváló és teljesítményorientált magatartásoknak nincsen hatása a lean technikák használatára. Bár több kutatásban is lenne mód hasonló klasszifikációra, a kutatók erőfeszítései inkább a feltárt kapcsolatokra koncentrálódnak, és nem szánnak figyelmet az elözetesen esetleg várt, de elmaradt hatások számbavételére és ennek okaira.

\section{Hipotézis}

Az elvi megfontolások alapján egyértelmü, hogy a lean termelés és (a különféle) leadership (koncepciók) között kapcsolat azonosítható. A korábbi kutatások közül többel összhangban ez a munka arra a feltételezésre épít, hogy a leadership hatással lehet a lean technikák alkalmazására. Az azonosított kutatási rések közül hipotézisünkbe a teljesítményjavulás vizsgálatát is belefoglaljuk.

Hipotézis: A lean termelési technikák mediálják a vezetői magatartás teljesitményjavulásra gyakorolt hatását.

Várakozásunk szerint vezetők a vezetési magatartást fontosnak érzik a lean termelési technikák kiterjedtebb használata szempontjából, illetve érzékelik, hogy a lean fejlesztések hozzájárulnak a teljesítményjavításához. A vezetési jegyek egymással kapcsolatban lévő elemeit Gelei, Losonci és Matyusz (2015) alapján - vezetési magatartásnak nevezzük el.

A hipotézist az 50 főnél nagyobb magyar feldolgozóipar cégek körében vizsgáljuk. Szintén kutatási résként azonosítottuk, hogy döntően egy-egy vezetői szintet vizsgálunk. Munkákban a hipotézist a termelésvezetők és az ügyvezetők körében is teszteljük.

Az adatok elérhetősége miatt jelen kutatás a vezetői jegyek kapcsán a GLOBE kutatás változói egy halmazának felhasználása mellett döntött. A teljesítménymutatók körét eltérően határozzuk meg a két vizsgált vezetői szinten. A termelésvezetőhöz az operatív mutatók körét rendeljük hozzá, az ügyvezetőhöz pénzügyi-üzleti mutatókat.

\section{Adatbázis és minta Adatbázis}

Empirikus kutatásunk mintája a Budapesti Corvinus Egyetem Vállalatgazdaságtan Intézetében müködő Versenyképesség Kutató Központ (VKK) felméréséböl származik. A VKK 1996 óta ötször végzett vállalati adatfelvételt. Az egyes adatfelvételeken rendre négy válaszadó képviselte a vállalatot (ügyvezető, termelésvezető, pénzügyi vezető, marketingvezető). A vezetési jegyekkel kapcsolatos kérdések a 2004. és a 2009. évi felmérésben voltak elérhetők. A két felmérés közül - Gelei, Losonci, Toarniczky és Báthory (2013), illetve Gelei, Losonci és Matyusz (2015) hasonlóan - a 2009. évi adatokat választottuk. A mintából csak azon feldolgozóipari cégeket elemeztük, amelyeknél legalább 50 fó volt a foglalkozta- 
tottak létszáma. A cég iparági besorolását és méretét az ügyvezetői kérdőív alapján végeztük el.

\section{Változók}

A VKK kérdőívei közül az ügyvezető és a termelésvezető kérdőíveiben elérhető vezetési jegyeket használtuk fel. A GLOBE vezetési jegyei közül 29 darab került be a kérdőívbe, illetve plusz elemként megjelent a környezetbarát jegy. Az empirikus elemzéseknél a környezetbarát jegytől eltekintettünk, mivel nem volt benne az eredeti változókészletben. A 29 jegyből 18 jelenik meg Hanges és Dickson kutatásában. Szintén 18 - bár részben más - jegy jelenik meg a referenciaként kiválasztott két magyar kutatásban is. A vezetési jegyek értékelésénél a válaszadók adott tulajdonság kiváló vezetővé váláshoz való hozzájárulásának mértékét értékelték 1-7 skálán, ahol 1 a nagymértékben gátoló és 7 a nagymértékben hozzásegítő jelentésű (lásd 1. melléklet és 3. táblázat). Bár a válaszadó általában a kiváló vezetőről nyilatkozik, a válaszok értelmezésénél úgy járunk el, hogy saját magát minősíti.

A lean termelési technikákat Gelei, Losonci, Toarniczky és Báthory (2013), valamint Gelei, Losonci és Matyusz (2015) alapján határoztuk meg. Ezek a lean technikák egyaránt lefedik a „szoftabb” (delegáció és felhatalmazás, folyamatos fejlesztés) és a „hardabb” (folyamatszervezés, húzásos termelés, minőség, karbantartás) lean elemeket (lásd 4. táblázat). Ugyanezen a lean technikákat reprezentáló változók a nemzetközi kérdőívekben (International Manufacturing Strategy Survey lean termeléssel kapcsolatos változói azonosak), illetve nemzetközi kutatásokban is használatosak (lásd Demeter - Matyusz, 2011). A lean termelési technikákkal kapcsolatban a termelésvezető válaszai érhetők el. A termelésvezető 1-5 skálán értékelte az egyes technikákkal kapcsolatban az elmúlt három év erőfeszítéseit, ahol 1 a semmi erőfeszítésre és 5 a nagyon sok erőfeszítésre utal. Empirikus kutatásunkban a termelésvezető válasza alapján értékeljük mindkét modellben a szervezet lean érettségét.

Az ügyvezető és a termelésvezető a teljesítménymutatók eltérő körét értékelte. A termelésvezető kérdőívéből azon 8 operatív mutatót emeltük ki, amelyek a termelés- és szolgáltatásmenedzsment versenyelőny-forrásaihoz kapcsolhatók (Demeter, 2014): ár (gyártási/szolgáltatásnyújtási egységköltség, készletforgás), minőség (gyártás/szolgáltatásnyújtás minősége; termék/szolgáltatás minősége és megbízhatósága), megbízhatóság (rendelésteljesítés pontossága, megbízhatósága), rugalmasság (mennyiségi, mix rugalmasság) és gyorsaság (rendelésteljesítési idő; gyártási átfutási idő). A válaszadónak e változók becsült értékének alakulását kellett egy ötfokozatú, „lépcsős” skálán elhelyeznie, ahol a több mint 25\%-kal romlott és a több mint 25\%-kal javult a válasz a két szélső értéknél (lásd 3. táblázat). Az ügyvezetők a teljesítményt pénzügyi-üzleti mutatók, mint (1) árbevételarányos nyereség, (2) tőkejövedelmezőség és (3) piaci részesedés, illetve általánosabb jellemzők mentén értékelték, mint (4) a technológia, (5) a menedzsment és (6) a termék/szolgáltatás minősége (lásd 3. táblázat). Az ügyvezetők 1-5 skálán értékeltek minden változót, ahol 1 a mélyen iparági átlag alatti szintet, az 5 az iparágban élenjáró színvonalat jelenti.

\begin{tabular}{|c|c|}
\hline Változó csoport & Változó név \\
\hline \multirow{29}{*}{ Vezetői jegyek } & Fejlődésorientált \\
\hline & Parancsolgató \\
\hline & Inspiráló \\
\hline & Kockázatvállaló \\
\hline & Könyörtelen, kegyetlen \\
\hline & Együttműködő \\
\hline & Autokrata \\
\hline & Baráti \\
\hline & Formális \\
\hline & Bátorító \\
\hline & Konzultáló \\
\hline & Kockázatkerülő \\
\hline & Diktatórikus \\
\hline & Óvatos \\
\hline & Öntelt \\
\hline & Előrelátó \\
\hline & Nem egyenlőségpárti \\
\hline & Előrelátás képessége \\
\hline & Motivációt felkeltő \\
\hline & Kommunikatív \\
\hline & Kiválóságorientáltság \\
\hline & Nem delegáló \\
\hline & Bizalomépítő \\
\hline & Nem résztvevő \\
\hline & Elitista \\
\hline & Teljesítményorientált \\
\hline & Motiváló \\
\hline & Mikrovezető \\
\hline & Uralkodó \\
\hline \multirow{6}{*}{$\begin{array}{l}\text { Lean termelési } \\
\text { technikák }\end{array}$} & Munkaerő tudásának növelése \\
\hline & Folyamatos fejlesztési programok \\
\hline & \begin{tabular}{|l|}
$\begin{array}{l}\text { Folyamatfókusz és } \\
\text { áramvonalasítás }\end{array}$ \\
\end{tabular} \\
\hline & Húzásos termelés \\
\hline & Minőségjavítási és ellenőrzés \\
\hline & $\begin{array}{l}\text { Gépek termelékenységének } \\
\text { fokozása }\end{array}$ \\
\hline \multirow{6}{*}{$\begin{array}{c}\text { Ügyvezető által } \\
\text { értékelt } \\
\text { teljesítménymutatók }\end{array}$} & Árbevétel-arányos nyereség \\
\hline & Tőkejövedelmezőség \\
\hline & $\begin{array}{l}\text { Piaci részesedés } \\
\text { (az árbevétel alapján) }\end{array}$ \\
\hline & Technológiai színvonal \\
\hline & Menedzsment \\
\hline & Termék/szolgáltatás minőség \\
\hline \multirow{8}{*}{$\begin{array}{l}\text { Termelésvezető által } \\
\text { értékelt } \\
\text { teljesítménymutatók }\end{array}$} & $\begin{array}{l}\text { Gyártás/szolgáltatásnyújtás } \\
\text { minősége }\end{array}$ \\
\hline & $\begin{array}{l}\text { Termék/szolgáltatás minősége és } \\
\text { megbízhatósága }\end{array}$ \\
\hline & Mennyiségi, mix rugalmasság \\
\hline & Rendelésteljesítési idő \\
\hline & $\begin{array}{l}\begin{array}{l}\text { Rendelésteljesítés pontossága/ } \\
\text { megbízhatósága }\end{array} \\
\end{array}$ \\
\hline & $\begin{array}{l}\text { Gyártási/szolgáltatásnyújtási } \\
\text { egységköltség }\end{array}$ \\
\hline & Gyártási átfutási idő \\
\hline & Készletforgás \\
\hline
\end{tabular}

3. táblázat A 2009-es VK kérdőív adatbázisának használt változói 


\section{A végső minta kialakítása és jellemzői}

Hipotézisünk teszteléséhez használt modellünkben parciális legkisebb négyzetek módszert (PLNM) alkalmazunk, ami nem igényel előfeltevéseket a sokaság eloszlására nézve. A számításokat az $\mathrm{R}$,semPLS” csomag alkalmazásával végezzük az R 3.4.3. verziójában. (Monecke - Leisch, 2012)

A VKK 2009-es adatbázisa 301 vállalat vezetőinek válaszait tartalmazza. A kérdőívekből felhasznált változók körében nem elhanyagolható mértékủ a hiányzó értékek aránya. A hiányzó értékek miatt egy változót sem kell elhagyni a vizsgálatból, mivel a hiányzó értékek aránya egy változó esetében sem haladja meg a 15\%-ot. Véletlenszerü, mintázatot nem mutató hiányzó értékek egy mérési skálának megfelelő helyzetmutatóval pótolhatók. A hiányzó értékek Little-féle MCAR teszt alapján $(\alpha=5 \%$-os szignifikanciaszinten) mindkét vezetői szinten mintázatot mutatnak (4. táblázat).

\begin{tabular}{|c|r|r|}
\hline & \multicolumn{1}{|l|}{ Ügyvezetö } & \multicolumn{1}{|c|}{ Termelésvezetö } \\
\hline $\boldsymbol{\chi 2}$ & 3740,718 & 2491,521 \\
\hline szabadságfok & 3537 & 2334 \\
\hline p-érték & 0,227395 & 0,01174624 \\
\hline
\end{tabular}

4. táblázat Az MCAR teszt eredményei a $301 \mathrm{db}$ rekordra

Ezek után kétszintű szủrést alkalmaztunk. Először eltávolítottuk a $10 \%$-nál több hiányzó értékkel rendelkező válaszadókat az adatbázisokból. Majd kutatásunk fókuszának megfelelően a legalább 50 fö́t foglalkoztató feldolgozóipari vállalatok vezetőinek válaszaira szükítettük a mintát. Az így adódó 73 elemü mintára az MCAR próbák eredményei alapján ( $\alpha=5 \%$-on) elfogadhatjuk a hiányzó értékek véletlenségének nullhipotézisét (5. táblázat). A véletlenszerüen hiányzó értékeket helyzetmutatóval (a mérési skálából kifolyólag módusszal) pótoltuk.

\begin{tabular}{|c|r|r|}
\hline & \multicolumn{1}{|c|}{ Ügyvezető } & Termelésvezető \\
\hline $\boldsymbol{\chi 2}$ & 681,0001 & 893,746 \\
\hline szabadságfok & 671 & 863 \\
\hline $\mathbf{p}$-érték & 0,3859802 & 0,227395 \\
\hline
\end{tabular}

5. táblázat Az MCAR teszt eredményei a szűkített, $73 \mathrm{db}$ rekordra

A kilógó értékektől is megtisztítottuk az adatbázist. A kilógó értékek vizsgálatát a változók interkvartilis terjedelmei alapján külső kerítések (alsó és felső) segítségével végeztük el. Ezek alapján a vezetési jegyek körében mért kilógó érték miatt további 7 vállalatot hagyunk el (ügyvezetők miatt 4 , termelésvezetők miatt 3 céget).
A 66 vállalatot tartalmazó végleges mintánk összetételét az 1. ábra foglalja össze. Mintában szereplő vállalataink jellemzően 50-299 fö közötti létszámmal rendelkező gépipari (vagy egyéb feldolgozóipari) vállalatok, többségében hazai (nem állami) tulajdonban. A legtöbb vállalat a Közép-magyarországi régióból került a mintába, a Középdunántúli régiót 5 vállalat képviseli.

\begin{tabular}{|c|c|}
\hline 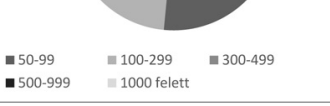 & 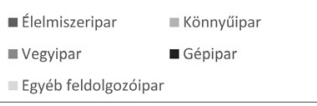 \\
\hline $\begin{array}{l}\text { (a) minta összetétele } \\
\text { létszám (fő) szerint } \\
\text { (cégek száma) }\end{array}$ & $\begin{array}{l}\text { (b) minta összetétele } \\
\text { ágazat szerint } \\
\text { (cégek száma) }\end{array}$ \\
\hline $\begin{array}{l}\text { - Többségi íllami } \\
\text { = Toóbségi befö́ldi (nem állami) }\end{array}$ & 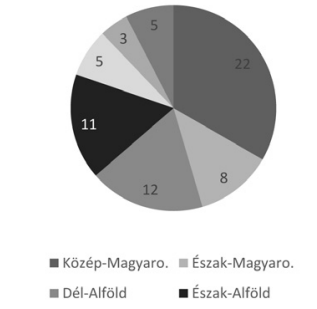 \\
\hline $\begin{array}{l}\text { (c) minta összetétele } \\
\text { tulajdonos szerint } \\
\text { (cégek száma) }\end{array}$ & $\begin{array}{l}\text { (c) minta összetétele } \\
\text { régiók szerint } \\
\text { (cégek száma) }\end{array}$ \\
\hline
\end{tabular}

\section{1. ábra A minta összetétele}

\section{A modellben használt változók kialakítása}

A továbbiakban használt modellek feltételezik, hogy a változóinkon értelmezhetőek az átlag, szórás, korreláció stb. mutatók. A kérdőívekben használt ordinális skálán mérhető változókat szükséges arány szintű mérési skálára hozni. A „kvantifikálási” műveletet Linting, Meulman, Groenen és van der Koojj (2007), valamint Abdi és Valentin (2007) alapján végeztük el. A kvantifikálás alapelve a Multiple Correspondence Analysis (MCA) alkalmazása. $^{2}$ A változók kvantifikálását az IBM SPSS 25 szoftver CATPCA makrójának segítségével végeztük el (Linting Meulman - Groenen - van der Koojj, 2007).

\section{Vezetői magatartások}

A kvantifikálás elvégzése után már lehetöségünk van a vezetői jegyekböl a vezetői magatartásokat tömörítő faktorok képzésére főkomponens analízis segítségével. A vezetői magatartások meghatározásánál több eltérő úton indultunk el.

\footnotetext{
${ }^{2}$ Az MCA nominális változók ábrázolását oldja meg egy „kisdimenziós” (legtöbbször kétdimenziós) térben. Az úgynevezett „,centroid” pontok koordinátái az egyes változók által felvehető értékek koordinátáinak átlagai. Ezen koordináták által megadott centroid pontokra egy regressziós egyenest illesztünk változónként, majd a regressziós egyenes pontjainak 2 db koordinátáját átlagoljuk. Így, a változó minden felvett értékéhez egy arányskálán mérhető számot tudunk rendelni az ordinális skálaértékek távolságai alapján egy kisdimenziós térben. Ezzel a számmal arányosan kijelölhető az adott ordinális változó értékeihez tartozó kvantifikált érték. Ez az elv az úgynevezett vektormodellen alapuló kvantifikálás.
} 
Először azon faktorokat kíséreltük meg felépíteni ügyvezetői szinten, melyek Hanges és Dickson (2004) munkájában is szerepelnek (18 kapcsolódó változónk volt, lásd 1. melléklet). Ezek alapján az ügyvezetők körében a nemzetközi szerzőpáros faktoraihoz közel álló három magatartást határoztunk meg: csoportorientált (konzultáló, kommunikatív), karizmatikus (fejlődésorientált, előrelátó, motivációt felkeltő, kiválóságorientált, teljesítményorientált) és részvételi (parancsolgató, autokrata, diktatórikus, nem egyenlőségpárti, nem delegáló, elitista, mikrovezető). E három faktor mellett egy ,énközpontú” (formális, nem résztvevő) magatartás is jelen volt alacsony konzisztencia mértékkel $(\alpha=0,428<0,5$, lásd DeVellis, 2016). Ezen faktorokra alkalmazása nem vezetett konzisztens eredményre a termelésvezetők körében.

Második megközelítésünkben a 29 változóból építkeztünk az ügyvezetők körében. A kiinduló 29 vezetői jegyet leíró változó mellett még véletlenszerüen $4 \mathrm{db}, 20 \mathrm{db}$ változóból álló részhalmazt képeztünk. Módszertani megfontolások alapján tisztítottuk ezeket a halmazokat pl. a magatartásnál a loading alapján nem egyértelmü, hogy melyik fökomponensbe tartoznak, vagy a KMO statisztikájuk 0,5 alatti értékü. E végső változóhalmazokból képzett faktorok közül azokat használjuk fel a továbbiakban, melyek az eredeti változók varianciájának legnagyobb hányadát megőrizték. E megközelítéssel az ügyvezetők körében elöállított faktorok alkalmazásával a termelésvezetők vezetési magatartása is meghatározható volt. Ezen az elven keletkezett faktorok összesítő táblája a 6. táblázatban található.

A 6. táblázat alapján elmondhatjuk, hogy a második úton kapott, azaz a 29 változóból épített faktoraink mindegyi-
Dickson eredeti faktorainak. Faktoraink a felhasznált változók varianciájának jelentős hányadát, 77,28\%-át magyarázzák. A végső főkomponenseket alkotó változókból álló minta KMO értéke 0,727, ami meghaladja a 0,5-ös küszöbértéket. A formális elnevezésű faktor egy változóból áll, így ennek $\alpha$ konzisztencia mutatója triviálisan a legmagasabb, 1 értéket veszi fel. Egy ilyen faktor szerepeltetése a modellben hordoz némi kockázatot (Diamantopoulos - Fuchs, 2009).

A 6. táblázatban szintén láthatók a termelésvezetői szinten (a második úton, azaz a 29 változóból felépített) képzett faktorok. A termelésvezetők faktorai a felhasznált változók varianciájának kimondottan magas hányadát, 85,90\%-át magyarázzák. A végső főkomponenseket alkotó változókból álló minta KMO értéke 0,766, ami meghaladja a 0,5ös küszöbértéket. A termelésvezetői faktorok nem annyira konzisztensek, mint az ügyvezetői szinten képzett faktorok, mivel eleve kevesebb változó szerepel a végső halmazban, és a Fejlődésorientált faktor Cornbach-féle $\alpha$ mutatója a legalacsonyabb elfogadható tartományba $(0,5-0,6)$ esik (DeVellis, 2016), illetve két önálló faktorunk is keletkezett.

A magatartásokat leíró faktorok értékelését 4 szempont szerint végeztük el Hair Jr, Hult, Ringle és Sarstedt (2016), valamint Peng és Lai (2012) alapján. Az első szempont a faktorok belső konzisztenciája, amit a Cornabch-féle $\alpha$ mutatóval mérünk. Általánosságban a faktoraink „,erős közepes” szintű konzisztenciával rendelkeznek ügyvezetői, és „kevésbé erős közepes" mértékű konzisztenciával bírnak termelésvezetői szinten. Második szempont faktoraink megbízhatósága. Ez annak a vizsgálatát jelenti, hogy a faktorhoz tartozó változók varianciájának mekkora hányadáért felelős a faktor,

\begin{tabular}{|c|c|c|c|c|}
\hline \multicolumn{2}{|c|}{ Ügyvezetők } & \multirow{2}{*}{ Hanges és Dickson faktor } & \multicolumn{2}{|c|}{ Termelésvezetők } \\
\hline Vezetői magatartás & Vezetési jegy & & Vezetői magatartás & Vezetési jegy \\
\hline \multirow{5}{*}{ Autokrata $(0,800)$} & Parancsolgató & \multirow{5}{*}{ Részvételi } & \multirow{5}{*}{ Autokrata $(0,765)$} & Parancsolgató \\
\hline & Könyörtelen, kegyetlen & & & Könyörtelen, kegyetlen \\
\hline & Autokrata & & & Autokrata \\
\hline & Diktatórikus & & & \multirow{2}{*}{ Diktatórikus } \\
\hline & Öntelt & & & \\
\hline \multirow{4}{*}{ Fejlődésorientált $(0,734)$} & Fejlődésorientált & \multirow{4}{*}{ Karizmatikus és Csoportorientált } & \multirow{4}{*}{$\begin{array}{l}\text { Fejlődésorientált } \\
\qquad(0,556)\end{array}$} & \multirow{2}{*}{ Fejlődésorientált } \\
\hline & Együttmüködő & & & \\
\hline & Bátorító & & & $V$ \\
\hline & Konzultáló & & & Konzuitaio \\
\hline \multirow{3}{*}{ Motiváló $(0,689)$} & Előrelátó & \multirow{3}{*}{ Karizmatikus } & \multirow{3}{*}{ Motiváló $(0,677)$} & Előrelátó \\
\hline & Teljesítményorientált & & & \multirow{2}{*}{ Motiváló } \\
\hline & Motiváló & & & \\
\hline \multirow{2}{*}{ Mikrovezető $(0,655)$} & Mikrovezető & \multirow{2}{*}{ Részvételi } & \multirow{2}{*}{ Mikrovezető (1) } & \multirow{2}{*}{ Mikrovezető } \\
\hline & Nem delegáló & & & \\
\hline Formális (1) & Formális & Énközpontúság & Formális (1) & Formális \\
\hline
\end{tabular}

6. táblázat Saját változókészlet alapján képzett ügyvezetői faktorok, Cornbach-féle $\alpha$ mutatójuk (zárójelben), valamint (Hanges - Dickson, 2004) faktoraihoz képesti megfelelőségük

ke meghaladja az elfogadható mértékü konzisztenciához szükséges 0,5-ös Cornbach-féle $\alpha$ értéket (DeVellis, 2016). Az így képzett saját faktoraink megfeleltethetők Hanges és azaz a változó loadingjának négyzetre emelését végeztük el. A legkisebb elfogadható érték az irodalomban általános ökölszabály szerint 40\%. Az értékelési eredmények alapján 
az ügyvezetők körében az együttműködő jegyet elhagytuk az elemzésekből. (A változóinkhoz kapcsolódó értékeket a 2. melléklet tartalmazza.) A minősítés 3. szempontja a kommunalitás, ami megmutatja, hogy a faktor hány százalékban magyarázza a faktorhoz tartozó változók varianciáját. A minimum követelmény, hogy a faktor a hozzá tartozó változók varianciájának legalább felét $(50 \%)$ megmagyarázza. Ez a kritérium minden vizsgált faktoron teljesül. (Az értékeket a 3. melléklet tartalmazza.) A negyedik értékelési szempont a faktorok diszkrimináló ereje a változók között. Ez a feltétel triviálisan teljesül, mivel a faktorképző változókat eleve úgy szelektáltuk meg, hogy ez a kritérium teljesüljön. (A különböző adatbázisok faktor-loadingjai a 4. mellékletben láthatók.)

\section{Lean termelési technikák és a teljesítménymutatók}

A lean technikák érettségi szintjét és az egyes vezetői szinteken a teljesítményjavulást leíró változókat korábbi kutatások változóhalmazai alapján választottuk ki. A létrehozott faktorok magas szintü konzisztenciát mutatnak a Cronbach-féle $\alpha$ mutató szerint (7. táblázat). Egyedül a termelésvezetői teljesítményjavulást értékelő mutatóknál kellett főkomponens-elemzést alkalmaznunk, amely következtében a nem egyértelmü loadinggal rendelkező változók szelekciója után két mutatót is definiálhatunk a termelésvezetők teljesítményének mérésére: minőségbeli teljesítményjavulás (Teljesítmény 1) és rendelésteljesítési teljesítményjavulás (Teljesítmény 2). A 7. táblázat adatai alapján e mesterségesen létrehozott teljesítményjavulási faktorok is erösen konzisztensek a Cronbach-féle alfa mutató alapján (kicsit még konzisztensebbek is, mint az ügyvezetői teljesítményt leíró faktor), illetve az őket alkotó változók varianciájának $89,67 \%$-át megőrzik.

\section{Eredmények}

Hipotézisünk szerint a lean technikák alkalmazása mediálja a vezetői magatartás teljesítményjavulásra gyakorolt hatását. A 2. ábrán látható oksági modelleket építettük fel a vezetési jegyek és az eredményesség között, a lean technikák mediáló hatását feltételezve.

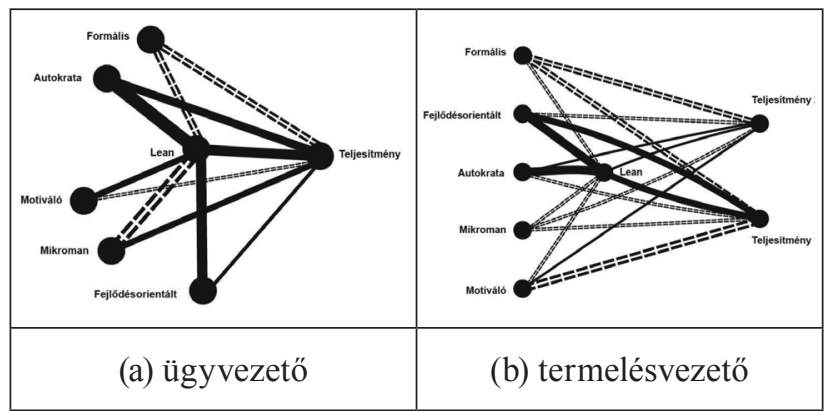

Megjegyzés: az élek vastagsága a hatás nagyságával arányos; folytonos él pozitív, szaggatott él negatív hatásra utal 2. ábra Oksági modellek eredményei

Az oksági modelljeinket két szempont alapján értékeljük: az endogén változók magyarázott varianciája és az egyes oksági irányok együtthatói által jelzett hatásnagyság alapján. Az eredmények a vizsgált vállalatok körében értékelendők. A modell általánosító képességét mérö mutatókat a kis mintaelemszám (66 vállalat) miatt nem vizsgáljuk.

Az endogén változók által alkotott faktorok magyarázott varianciáját az $\mathrm{R}^{2}$ mutató segítségével adhatjuk meg. A mutató egy faktor kivételével minden endogén faktor esetében a közepes magyarázóerő tartományában (10\%$50 \%) \operatorname{mozog}($ 8. táblázat).

\begin{tabular}{|l|c|c|}
\hline \multicolumn{1}{|c|}{ Endogén faktor } & \multicolumn{2}{|c|}{$\mathbf{R}^{\mathbf{2}}$} \\
\cline { 2 - 3 } & Termelésvezetö & Ügyvezető \\
\hline Lean & $21 \%$ & $29 \%$ \\
\hline Ügyvezető teljesítmény & $\mathrm{x}$ & $26 \%$ \\
\hline $\begin{array}{l}\text { Termelésvezetői } \\
\text { teljesítmény 1 } \\
\text { (minőség) }\end{array}$ & $19 \%$ & $\mathrm{x}$ \\
\hline $\begin{array}{l}\text { Termelésvezetői } \\
\text { teljesítmény 2 } \\
\text { (rendelésteljesítés) }\end{array}$ & $4 \%$ & $\mathrm{x}$ \\
\hline
\end{tabular}

8. táblázat Az oksági modellek endogén változóinak magyarázott varianciája

\begin{tabular}{|c|c|c|c|}
\hline \multicolumn{2}{|l|}{ Lean termelés } & \multicolumn{2}{|c|}{ Teljesítménymutatók } \\
\hline Lean termelési technikákat leíró változók & Faktor $(\alpha)$ & Teljesítményt leíró változók & Faktor $(\alpha)$ \\
\hline Munkaerő tudásának növelése & \multirow{6}{*}{ Lean $(0,879)$} & Árbevétel-arányos nyereség & \multirow{6}{*}{$\begin{array}{l}\text { Ügyvezetői teljesítmény } \\
\qquad(0,802)\end{array}$} \\
\hline Folyamatos fejlesztési programok & & Tőkejövedelmezőség & \\
\hline Folyamatfókusz és áramvonalasítás & & Piaci részesedés (az árbevétel alapján) & \\
\hline Húzásos termelés & & Technológiai színvonal & \\
\hline Minőségjavítás és ellenőrzés & & Menedzsment & \\
\hline \multirow[t]{5}{*}{ Gépek termelékenységének fokozása } & & Termék/szolgáltatás minőség & \\
\hline & & Gyártás/szolgáltatásnyújtás minősége & \multirow{2}{*}{$\begin{array}{c}\text { Termelésvezetői teljesítmény } \\
1 \text { (minőség) }(0,872)\end{array}$} \\
\hline & & $\begin{array}{l}\text { Termék/szolgáltatás minősége és } \\
\text { megbízhatósága }\end{array}$ & \\
\hline & & Rendelésteljesítési idő & \multirow{2}{*}{$\begin{array}{l}\text { Termelésvezetői teljesítmény } \\
2 \text { (rendelésteljesítés) }(0,886)\end{array}$} \\
\hline & & $\begin{array}{c}\text { Rendelésteljesítés } \\
\text { pontossága/megbízhatósága }\end{array}$ & \\
\hline
\end{tabular}

7. táblázat $A$ lean érettségét és a különböző vezetői szinteken érzékelt, teljesítményjavulást leíró faktorok 
A termelésvezetők 2. teljesítményjavulás mutatójának (rendelésteljesítés) varianciáját mindössze 4\%-ban magyarázza a lean technikák érettsége és a vezetői magatartások összessége, ami egy kifejezetten gyenge kapcsolat. A lean technikák alkalmazásának mélységét legnagyobb mértékben az ügyvezetői vezetési magatartásokkal tudjuk magyarázni, 29\%-ban. Hasonló nagyságrendben, 26\%-ban magyarázza együttesen az ügyvezetői vezetési jegyek és a lean technikák érettsége az ügyvezető által észlelt teljesítményjavulást mérő faktor varianciáját. Ezek már „gyenge közepes” szintü kapcsolatoknak minősíthetők.

Az oksági modelljeink egyes irányainak együtthatói, amiket a parciális legkisebb négyzetek elven megbecsültünk a semPLS nevű csomag használatával, már standardizált regreszsziós együtthatókként értelmezhetők. Az együtthatók abszolút értéke és elöjele alapján értékelni tudjuk a faktorok közötti hatásokat. Mivel exogén faktorainkat főkomponens módszerrel alkottuk meg, így azok definíció szerint korrelálatlanok, így multikollinearitási kérdésekkel nem kell foglalkoznunk.

Az egyes oksági irányokhoz tartozó együtthatók stabilitásának megvizsgálásához 500 replikációszámú bootstrap szimuláció segítségével megállapítottuk az egyes együtthatók tapasztalati eloszlásából azok szignifikanciáját $\alpha=5 \%$ és $\alpha=10 \%$ szignifikanciaszinten. A 9. táblázatban a hatásnagyságokat és azok stabilitását figyelhetjük meg.

\begin{tabular}{|l|c|c|}
\hline \multicolumn{3}{|c|}{ Hatások - Ügyvezetö 2009 } \\
\hline & Lean & Teljesítmény \\
\hline Autokrata & 0,490 & 0,197 \\
\hline Formalis & $-0,152$ & $-0,163$ \\
\hline FejlOrient & 0,375 & 0,030 \\
\hline MikroMan & $-0,285$ & 0,117 \\
\hline Motivalo & 0,113 & $-0,046$ \\
\hline Lean & - & 0,361 \\
\hline Teljesitmeny & - & - \\
\hline
\end{tabular}

\begin{tabular}{|l|c|c|c|}
\hline \multicolumn{4}{|c|}{ Hatások - Termelésvezetö 2009 } \\
\hline & Lean & $\begin{array}{c}\text { Telj_1 } \\
\text { (minőség) }\end{array}$ & $\begin{array}{c}\text { Telj_2 } \\
\text { (rendelés- } \\
\text { teljesítés) }\end{array}$ \\
\hline Autokrata & 0,362 & $-0,089$ & 0,036 \\
\hline FejlOrient & 0,375 & 0,276 & $-0,043$ \\
\hline Formalis & $-0,06$ & $-0,116$ & $-0,143$ \\
\hline Mikroman & 0,04 & $-0,073$ & $-0,063$ \\
\hline Motivalo & $-0,043$ & $-0,313$ & 0,096 \\
\hline Lean & - & $\mathbf{0 , 2 0 5}$ & 0,06 \\
\hline Telj_1 & - & - & - \\
\hline Telj_2 & - & - & - \\
\hline
\end{tabular}

Megjegyzés: A világos szürkével jelölt együtthatók 10\%-on, míg a sötétszürkével jelölt együtthatók 5\%-on szignifikánsak.

A fékövérrel szedett együtthatók nem szignifikánsak, ám jelentős hatásnagyságot képviselnek.

9. táblázat Az oksági modellek együtthatóinak szignifikanciája

A 10. táblázatban jelenítjük meg a hipotézisünk által lefedett közvetlen és közvetett kapcsolatokra jellemző eredményeket.

\begin{tabular}{|c|c|c|c|}
\hline $\begin{array}{l}\text { Kapcsolatok } \\
\text { a modellben }\end{array}$ & Ügyvezetők & $\begin{array}{c}\text { Termelés- } \\
\text { vezetők }\end{array}$ & Megállapítás \\
\hline $\begin{array}{l}\text { A vezetési } \\
\text { magatartás } \\
\text { közvetlen } \\
\text { hatása a lean } \\
\text { termelési } \\
\text { technikák } \\
\text { használatára. }\end{array}$ & $\begin{array}{l}\text { Autokrata-> } \\
\text { Lean } \\
\text { FejlOrient-> } \\
\text { Lean } \\
\text { MikroMan-> } \\
\text { Lean }\end{array}$ & $\begin{array}{c}\text { FejlOrient-> } \\
\text { Lean } \\
\text { Autokrata-> } \\
\text { Lean }\end{array}$ & $\begin{array}{l}\text { Pozitívan és } \\
\text { negatívan } \\
\text { ható vezetöi } \\
\text { magatartás is } \\
\text { azonosítható, } \\
\text { többségben } \\
\text { vannak } \\
\text { a pozitív } \\
\text { magatartások }\end{array}$ \\
\hline $\begin{array}{l}\text { A vezetési } \\
\text { magatartás } \\
\text { közvetlen } \\
\text { hatása a } \\
\text { teljesítmény- } \\
\text { javulásra }\end{array}$ & & $\begin{array}{c}\text { Motivalo-> } \\
\text { Teljesitmény } 1 \\
\text { (minöség) } \\
\text { FejlOrient-> } \\
\text { Teljesítmény } \\
\mathbf{1} \text { (minőség) } \\
\end{array}$ & $\begin{array}{l}\text { Közvetlen } \\
\text { hatás csak } \\
\text { a termelés- } \\
\text { vezetők } \\
\text { körében. }\end{array}$ \\
\hline $\begin{array}{l}\text { A lean } \\
\text { technikák } \\
\text { mediáló } \\
\text { hatása }\end{array}$ & $\begin{array}{l}\text { Lean-> } \\
\text { Teljesítmény }\end{array}$ & $\begin{array}{c}\text { Lean-> } \\
\text { Teljesítmény } 1 \\
\text { (minőség) }\end{array}$ & $\begin{array}{l}\text { A hipotézist } \\
\text { elfogadjuk. }\end{array}$ \\
\hline
\end{tabular}

Megjegyzés: Szürkével szedett betük utalnak a negatív hatásokra, félkövér fekete betük utalnak a pozitív hatásokra. Dölttel szedett hatások csak 10\%-on szignifikáns hatások vagy a standardizált együtthatója alapján jelentős hatás, de $10 \%$-on sem szignifikáns.

10. táblázat Az oksági modellek irányai hatásnagyság szerinti sorrendben.

A lean technikák érettségét mindkét vezetői szinten két magatartás erősíti: a fejlődésorientált és az autokrata. Az ügyvezető mikrovezető viselkedése negatívan hat a leanre. Ügyvezetői szinten a teljesítményjavulást mérő mutatókra közvetlen hatása nincs a vezetési jegyeknek, csupán közvetetten a lean technikákon keresztül érvényesülnek a teljesítménymutatókban. A mikrovezetö magatartás közvetve csökkenti, az autokrata és a fejlödésorientált közvetve növeli a lean technikákon keresztül az ügyvezetök körében a teljesitményjavulást. Termelésvezetői szinten a motiváló magatartás az első típusú teljesítménymutatók (minőség) romlását eredményezi direktben. Egyedül a fejlődésorientált magatartásnak van pozitív hatása a minőségi teljesítményjavulást mérő faktorra a termelésvezetők körében. A termelésvezetők körében a minőség teljesítményjavulás faktorra a lean technikáknak is jelentős hatása van, ám a hatás nem szignifikáns (minta összetételének kis megváltozására eltűnik a hatás).

Hipotézisünk a lean technikák mediáló hatását feltételezi. A lean technikák mediáló hatása egyértelmű az ügyvezetők körében. A termelésvezetők körében a mediáló hatás a mintában erős, viszont nem szignifikáns. Ezek alapján a hipotézisünket elfogadjuk.

\section{Eredmények értelmezése}

Öt dimenzióban emeljük ki hozzájárulásunkat a tudományos diskurzushoz. A hazai leadership eredményekhez kapcsolódik, hogy (1) rávilágítottunk a hazai környezetben markánsan megjelenő vezetési magatartásokra. A lean kontextusban vizsgálódó munkákhoz azzal adtunk hozzá, hogy (2) több vezetői pozícióban vizsgálódtuk, illetve a (3) 
magatartás és a lean alkalmazás közötti kapcsolat mellett a (4) lean mediáló hatását is elemeztük a teljesítményjavulásra. (5) Végül számba vesszük az alkalmazott módszertan jellemzőit is.

(1) Mintánkban a vezetési jegyek hat magatartásra utalnak. Ezek közül kettő kapcsolható szorosan a korábbi eredményekhez. Az autokrata magatartást lefedi a Bakacsi és Takács (1998) eredményei szerinti kiskirály faktor, míg a mikrovezető magatartást a Karácsonyi (2006) által nem-delegálónak hívott faktor. Ez a két magatartás a nemzetközi irodalomban irányadónak tekintett forrásban Hanges és Dickson (2004) a részvételi faktorhoz kapcsolódik. Ezek alapján a részvételi faktor - bár eltérö elsödleges faktorokra épitve, de - meghatározó magatartása a hazai vezetőknek. Fejlődésorientált faktorunk kapcsolódik még két-két jegyen keresztül az idézett két hazai munkához: a konzultáló és bátorító jegyen keresztül a hiteles-participatív (Bakacsi - Takács, 1998) és a fejlődésorientált és bátorító jegyen keresztül a hiteles-fejlesztő (Karácsonyi, 2006) faktorokhoz. A fejlődésorientált magatartás a karizmatikus (teljesítményorientált elsődleges faktor) és a csoportorientált (együttműködő és csoportintegrátor elsődleges faktor) faktorokhoz is illeszkedik (Hanges - Dickson, 2004).

(2) A vezetőket lean kontextusban vizsgáló korábbi hazai munkákkal több következtetésünk összhangban van. Kutatásunk Gelei, Losonci és Matyusz (2015) munkájával átfedő, bár némileg eltérő jegyekre építő magatartásokat definiált a termelésvezetők körében ${ }^{3}$. Söt, arra hívjuk fel a figyelmet, hogy a magatartások az ügyvezetői szinten is hasonlóak. E tekintetben eredményeink összhangban vannak egy másik korábbi hazai munkával is (Losonci Kása - Szántó - Zoltayné, 2018), ami a nehezen fejleszthető kompetencia komponensekkel (pl. érték, attitüd) (Spencer - Spencer, 1993, p. 15. idézi: Szőts - Kováts, 2007) (pl. kockázatvállalási hajlandóság, üzleti érzék) kapcsolatban állapította meg a termelésvezetők és az ügyvezetők hasonló észlelését.

Lean kontextusban markánsan jelen vannak a vezetői stílus eltéréseit kiemelő munkák is, legyen szó a vezetői szintek közötti eltérésekről vagy a lean érettséggel változó stílusról (Tortorella - Fogliatto, 2017; Tortorella - Fettermann - Anzanello - Sawhney, 2017). Mi a vezetői szinteken tapasztalt eltérések helyett a két vezetői szint közötti hasonlóságot látjuk elsődlegesnek. Ez magyarázható a kutatásunkba bevont kisebb szervezeti méretekkel, ami végső soron kisebb differenciálódást jelenthet.

(3) Eredményeink megerösítik, hogy a leadership hat a lean technikákra (Gelei - Losonci - Matyusz, 2015; Zarinah - Farhana - Nadiah, 2017). A fejlödésorientált és az autokrata magatartás pozitív hatása emelhetö ki mind az ügyvezetök, mind a termelésvezetők körében. A fejlődésorientált magatartás pozitív hatása összecseng a korábbi kutatások eredményeivel. Ez a magatartás kapcsolatba hozható a lean kontextusban tetten érhető kapcsolatorientált, coachingot és támogatást biztosító vezetői stílussal is (Tortorella - Fogliatto, 2017; Tortorella - Fettermann Anzanello - Sawhney, 2017).

Az autokrata magatartás pozitív hatása meglepő. Korábbi kutatásban az autokrata stílus negatív hatással bírt (Zarinah - Farhana - Nadiah, 2017), illetve az autokrata magatartás hatása semleges volt (Gelei - Losonci - Matyusz, 2015). A pozitív hatásra a minta adatainak további elemzésével részleges magyarázatot kaphatunk. Mintánkban a vezetési jegyek háromdimenziós térbe történő leskálázásával (ALSCAL algoritmussal négyzetes euklideszi távolságokat alkalmazva) az ügyvezetők körében három vezetői magatartást hoztunk létre, és ebben az esetben a motiváló faktorba sorolt motiváló vezetési jegy a háromdimenziós térben viszonylag közel helyezkedik el az autokrata faktorokhoz tartozó vezetési jegyekhez (lásd 5. melléklet). Ez arra utalhat, hogy idehaza az autokrata magatartás a teljesítményhez, az ösztönzéshez is kapcsolódik. Emiatt meglátásunk szerint szakmai narratívákban is nagyobb figyelmet érdemel az autokrata magatartás elemzése. Tömegtermelési (Wilkinson - Gamble - Humphrey - Morris - Anthony, 2001) vagy lean környezetben (Lowe, 1993) is találkozhattunk korábban diktatórikus vagy autokratikus vezetői megnyilvánulásokkal, eleddig ezek mélyebb vizsgálata azonban elmaradt.

A mikromenedzser magatartás megitélése ellentmondásos: a termelésvezetők körében nincsen hatása, az ügyvezetök körében negatív a hatása. A nemdelegáló jegyet is magában hordozó mikromenedzserrel kapcsolatos eredmény tehát (Zarinah - Farhana - Nadiah, 2017) kutatásával állnak összhangban, míg e magatartás enyhe pozitív hatását kiemelő munkával (Gelei - Losonci - Matyusz, 2015) ellentétes megállapításra jutottunk.

Összességében elmondhatjuk, hogy a fejlödésorientált magatartás pozitív hatása és a mikrovezető negatív hatása összhangban van a kutatói és a gyakorlati közösség által osztott lean vezető képpel (lásd Liker lean alapelveit Gelei - Losonci - Toarniczky - Báthory, 2013 munkájában). Az autokrata magatartás azonban szembe megy ezzel a lean vezetö képpel.

(4) Legfontosabb empirikus hozzáadott értékünk a lean mediáló hatásának vizsgálatához kapcsolódik. A leadershippel foglalkozó munkák idehaza eleddig, vagy megelégedtek a vezetői faktorok azonosításával (lásd Bakacsi és Takács, 1998; Karácsonyi, 2006) vagy azzal, hogy a koncepció használata/sikere volt a teljesítmény mércéje (Gelei - Losonci - Matyusz, 2015; Blaskovics, 2015). A nemzetközi leanes irodalomban a teljesítményjavulást leképező változók széles körének és a két vezetői szint együttes megjelenítése bír újdonságértékkel.

\footnotetext{
${ }^{3}$ Az egyetlen teljesen azonos magatartás a formális, amely a formális jegyet takarja. A további átfedő magatartások mögött eltérnek a kapcsolódó jegyek. Ide sorolható az autokrata magatartás, amelyben az autokrata és a diktatórikus jegyek azonosak a két vizsgálatban. Vagy a mikrovezető magatartás, amelyben csak a mikrovezető jegy azonos. Eltérő megnevezés ellenére átfedést mutat a korábbi kutatás kommunikatív magatartása és e kutatás fejlődésorientált magatartása, pl. fejlődésorientált és konzultáló jegyekben.
} 
A két vezetői szint eltéröen észleli a lean mediáló hatását: az ügyvezetők körében a mediáló hatás pozitiv, a termelésvezetőknél a mediáló hatás nem stabil. Az ügyvezetök körében tehát a magatartás is „,csak” a lean technikákon keresztül vezet jobb teljesítményhez. A termelésvezetők észlelése részben meglepő, lévén nem köszön vissza a lean és az operatív mutatók közötti pozitív kapcsolat (Demeter - Matyusz, 2011; Kovács - Rendesi, 2015). Az, hogy a hazai tapasztalatok nem minden esetben támasztják alá a lean és a versenyképesség kapcsolatát (Losonci - Borsos, 2015) magyarázható azzal, hogy a VKK adatbázisát dominálják a kis- és közepes vállalatok, míg a kutatások rendszerint a nagyvállalatokra építenek. Ez egyben fokozottan hívja fel a figyelmet arra a problémára, hogy a kisebb vállalatok kevésbé férnek hozzá a nagyvállalatoknál rendelkezésre álló és eredményesen használt leannel kapcsolatos tudáshoz (Demeter - Losonci - Kovács, 2017).

Eredményeink egyértelmüek a tekintetben, hogy a termelésvezetők a lean technikák alkalmazásával kapcsolatban fontosnak gondolják a magatartások hatását. Sőt, e vezetői szint alapvetően a magatartásokhoz köti a teljesítményjavulást is. Ellentmondás abban látható, hogy a termelésvezetőknél a fejlődésorientált magatartás pozitív hatása mellett a motiváló magatartás negatívan hat. Különösen annak fényében meglepő ez a dichotómia, hogy e két magatartáshoz olyan jegyek kapcsolódnak, amelyek a karizmatikus faktorba sorolhatók (Hanges - Dickson, 2004). Nehezen magyarázható a hatás iránya is, mivel a lean szellemiség alapján a motiváló (előrelátó és motivációt felkeltő jegyek) magatartás inkább pozitív hatást feltételez.

Végül, mivel Gelei, Losonci, Toarniczky és Báthory (2013), illetve Gelei, Losonci és Matyusz (2015) korábbi munkáira több ponton is építettünk, célszerü tételesen is számba venni e kutatás sajátos vonásait. Közös a kutatásokban a kontingencialista felfogás, a jegyek hatásának vizsgálata a lean gyakorlatok használatára, illetve az adatbázis. Jelen munka karakteresen a termelésvezetők mellett az ügyvezetőket is vizsgálja. A vezetési magatartások meghatározása is eltér: Gelei, Losonci, Toarniczky és Báthory (2013), valamint Gelei, Losonci és Matyusz (2015) elvi megfontolások alapján indul el 20 jeggyel, jelen munka statisztikai megfontolásokat követve a 29 jegyböl „alulról” építkezik. Leglényegesebb eltérés, hogy a teljesítményre gyakorolt direkt és indirekt hatások csak e munkában jelentek meg.

(5) A kérdőíves lekérdezésen alapuló, kvantitatív elemzést tartalmazó kutatásnak kulcsfontosságú elemei a dimenziócsökkentés, faktorképzés és a faktorok felhasználásával regressziós vagy klaszterezési modell építése, pl. Nagy és Berács (2012), Lippert, Gaál és Kovács (2015), Hofmeister Tóth, Kopfer-Rácz és Sas (2015), Losonci és Borsos (2015), Benedek és Takácsné György (2016), Takács, Németh, Klér és Toarniczky (2017). Mind a főkomponens, mind a föfaktorelemzések elöfeltétele, hogy a felhasznált változók arány skálán adottak legyenek (Kovács, 2011), míg minden Likert vagy hasonló skálán adott változó ordinális skálán mér. E feltételt ritkán veszik figyelembe a szerzők. Kovács (2011) javaslatai alapján többdimenziós skálázás (Multidimensional scaling, MDS) segítségével kezeli a módszertani problémát Dörnyei (2010) és Hortoványi (2010). Jelen kutatás módszertani újdonsága, hogy egy, az MDS-hez hasonló módszert (MCA) felhasználva kvantifikáljuk a változókat, és így alkalmazunk főkomponens-elemzést adatbázisunk változóin. A módszer előnye az MDS-hez képest, hogy az új változók korrelációmátrixának sajátértékei alapján már tudunk következtetni a faktorok számára (mint a hagyományos fökomponens-elemzésben), nem szükséges az összes lehetséges faktorszámra felépíteni a modellt, mint az MDS esetében.

\section{Konklúzió}

A lean menedzsment nehézkes adaptálása miatt az utóbbi években előtérbe került a vezetők kutatása. Cikkünkben azt elemeztük, hogy hogyan mediálják a lean technikák a vezetési magatartás teljesítményjavulásra gyakorolt hatását.

Az általunk vizsgált két vezetői szinten (ügyvezető, termelésvezető) a vezetési magatartások hasonlóságot mutatnak. Az ügyvezetők és a termelésvezetők észlelése nagyrészt megegyezik a lean termelési technikák használatára pozitívan ható magatartásokban (fejlödésorientált, autokrata) is. Úgy tünik, hogy a feldolgozóiparban két nagyon eltérő magatartásra építve adaptálják a leant. Az eredményesnek tűnő autokrata magatartás elterjedtsége mindenképpen több figyelmet érdemel. Egyértelmü bizonyítékot találtunk arra, hogy a magatartásnak jelentős hatása van a teljesítményjavításra. Míg az ügyvezetők körében a magatartás közvetlenül és a lean technikákon keresztül közvetve is hatnak a teljesítményjavulásra, addig a termelésvezetők körében csak a magatartásoknak van közvetlen hatása. Miközben tehát a szakmai diskurzusban az elmúlt években tudatosult, hogy lean kontextusban meghatározó hatású a vezetői magatartás, addig adataink arra utalnak, hogy a vezetők körében ez már egy régebb óta felismert jelenség.

Eredményeink alapján a menedzsereknek is tehető néhány javaslat. Érdemes lehet az autokrata magatartás eredményességével kapcsolatos előfeltevések felülvizsgálata. Könnyen lehet, hogy emiatt a leanben rejlö ,,bottom-up" potenciálról mond le a vállalat, ahogyan erre már Gelei, Losonci, Toarniczky és Báthory (2013) is utaltak. A napi tapasztalatokat tükrözhetik eredményeink, amikor azt mutatják, hogy a termelésvezetőknél stabilabb és erősebb a magatartások hatása a teljesítményjavításra, mint a lean rendszeré. Ez meglátásunk szerint nem leértékeli a lean rendszerrel kapcsolatos tudást és erőfeszítéseket, hanem éppenséggel felértékeli. A lean elmélyült ismerete az alap, amelyben a magatartás az adaptálást és az üzemeltetést, azaz a hogyan kérdését támogatja.

\section{További kutatások és a kutatás korlátai}

A vizsgált vállalatok körére jó pontossággal illeszthetők modellek, amelyek megfelelően írják le a vezetői jegyek és a lean érettség szempontjából a mintát. A kis mintaelemszámok és módszertani megfontolások (pl. elemszám sokszor nem éri el a változószám ötszörösét, statisztikai próbák alkalmazásának feltételei) miatt az 
eredményeink és a szignifikáns hatások csak a vizsgált vállalatok körében tekinthetők érvényesnek. Azt le lehet belölük szürni, hogy a mintaösszetétel kis megváltozásának következményeképpen mely hatások válnak bizonytalanná, és mely hatások maradnak meg stabilabban. Fontosnak tartjuk továbbá megjegyezni, hogy az ügyvezetők és termelésvezetők szintjén az eredményességi mutatók ötfokozatú skálája eltérő jelentéstartalommal bír. Míg ügyvezetők esetében a vállalatukat a piaci átlaghoz viszonyították a válaszadók, addig a termelésvezetők a teljesítmény előjeles javulását adják meg saját vállalatuk korábbi állapotához képest. Emiatt a modelljeink eredményességre vonatkozó következtetései nem közvetlenül összehasonlíthatók a vizsgált két vezetési szint tekintetében.

A cikk bevezetőjében is utaltunk rá, hogy az utóbbi években a lean leadership előtérbe került. Már maga a fogalom terjedése is befolyásolhatja a vezetői észleléseket. A vezetői észlelések időbeli változásának körbejáráshoz jó alapot ad a VKK más adatfelvételeinek elemzése (pl. 2004. év) vagy esetleg további adatfelvétel.

A változókészlet is korlátot jelent, lévén a VKK kutatás célja a lehető legszélesebb vállalati információgyűjtés. Emiatt egy-egy témakör csak korlátozott változóhalmaz alapján kerül bele a kérdőívbe. Meglátásunk szerint a teljesítményjavulást értékelő mutatókat és a lean technikákat reprezentáló változók száma és minősége megfelelő. Korlátot jelenthet a teljesítményjavulást értékelő változók eltérő skálája. A GLOBE kutatásból átvett vezetési jegyek számunkra adottak voltak, azok célzottabb kiválasztása és/vagy nagyobb számban történő lekérdezésével érvényesebb megállapításokat lehetne tenni. Úgy véljük, hogy e korlátokkal használható változókészletből is értékes eredmények születtek.

Az eredmények fényében feltáró jellegű munka is indokolt. Az autokrata magatartás pozitív hatásának megértésére adódik elsődleges témaként. Különösen érdekes lenne a vezetői magatartás hatásának vizsgálata egy lean szervezeti transzformáció során.

A két koncepció közötti kapcsolat irányának körbejárása is adódik. Erre akár további kvantitatív elemzések, vagy az említett esettanulmányos kutatás is alkalmas lehet.

\section{Felhasznált irodalom}

Abdi, H. - Valentin, D. (2007): Multiple correspondence analysis. Encyclopedia of measurement and statistics, p. 651-657. Forrás: https://www.researchgate.net/profile/Dominique_Valentin/publication/239542271_Multiple_Correspondence_Analysis/ links/54a979900cf256bf8bb95c95.pdf

Bakacsi, Gy. - Sarkadi-Nagy, A. (2003): Latinos magyar leadership-vezetés felfogásunk a GLOBE-kutatás tükrében. Alkalmazott Pszichológia, 5(3-4), p. 7-26.

Bakacsi, Gy. - Takács, S. (1998): Honnan - hová? A nemzeti és szervezeti kultúra változásai a kilencvenes évek közepének Magyarországán. Vezetéstudomány, 29(2), p. $15-22$.

Bauer, D. (2013): Leadership és annak jellegzetességei a szlovák szervezetekben. A szlovákiai GLOBE kutatás eredményei. Budapest: Budapesti Corvinus Egyetem. doi:10.14267/phd.2015015

Beer, M. (2003): Why Total Quality Management Programs Do Not Persist: The Role of Management Quality and Implications for Leading a TQM Transformation. Decision Sciences, 34(4), p. 623-642. doi:10.1111/ j.1540-5414.2003.02640.x

Benedek, A. - Takácsné György, K. (2016): A felelős vállalatirányítás személyi tényezői: A CSR-központ felelős vállalatvezetők attitűdjének vizsgálata a kis- és középvállalatok körében. Vezetéstudomány/Budapest Management Review , 47(1), p. 58-67.

Berényi, L. (2017): A minőségirányítás fejlődése és jövőbeli lehetőségei. Vezetéstudomány, 48(1), p. 58-60. doi:10.14267/VEZTUD.2017.01.05

Blaskovics, $B$. (2015): A projektvezető vezetési stílusának hatása a projektsikerre - egy hazai vállalat példája alapján. Vezetéstudomány, 46(8), p. 14-23.

Camuffo, A. - Gerli, F. (2012): What do lean managers do? Modeling management behaviors in lean production environments. Working Paper Series. Venezia, Italy: Universitá Ca' Foscari Venezia, Department of Management. Letöltés dátuma: 10 November 2016, forrás: http://virgo.unive.it/wpideas/storage/2012wp13.pdf

Demeter, K. (2014): Értékteremtő folyamatok stratégiája. In: Demeter, K. (szerk.): Termelés, szolgáltatás, logisztika - Az értékteremtés folyamatai. Budapest: Complex Kiadó, p. 49-83.

Demeter, K. - Losonci, D. (2013): Lean production and business performance: international empirical results. Competitiveness Review: An International Business Journal, 23(3), p. 218-233. doi:10.1108/10595421311319816

Demeter, K. - Matyusz, Z. (2011): The impact of lean practices on inventory turnover. International Journal of Production Economics, 133(1), p. 154-163. doi:10.1016/j.ijpe.2009.10.031

Demeter, K. - Losonci, D. - Kovács, Z. (szerk.) (2017): A lean tudás megosztása. Budapest: Budapesti Corvinus Egyetem, Vállalatgazdaságtan Intézet

DeVellis, R. F. (2016): Scale development: Theory and applications (Vol. 26). Los Angeles: Sage publications

Diamantopoulos, A. - Fuchs, C. (2009): Using single-item measures for construct measurement in management research: Conceptual issues and application guidelines. Die Betriebswirtschaft, 69(2), p. 195. Forrás: https:// temme.wiwi.uni-wuppertal.de/fileadmin/_migrated/ content_uploads/fuchs_diamantopoulos_2009.pdf

Dörnyei, K. (2010): A csomagoláson található információtartalom újragondolása sokdimenziós skálázással az élelmiszeripar példáján (Rethinking of information content on food packaging using multidimensional scaling). Vezetéstudomány/Budapest Management Review, 41(12), p. 57-69.

Fuchs, C. - Adamantios, D. (2009): Using single-item measures for construct measurement in management research: Conceptual issues and application guidelines. Betriebswirtschaft, 69(2), p. 195. Letöltés dátuma: 2017. 10 22, forrás: https://search.proquest.com/ docview/750491294?pq-origsite $=$ gscholar 
Gelei, A. - Losonci, D. - Matyusz, Z. (2015): Lean production and leadership attributes - the case of Hungarian production. Journal of Manufacturing Technology Management, 26(4), p. 477-500. doi:10.1108/JMTM05-2013-0059

Gelei, A. - Losonci, D. - Toarniczky, A. - Báthory, Z. (2013): A lean menedzsment és a leadership jellemzők kapcsolata a hazai vállalati gyakorlatban. Vezetéstudomány, 44(4), p. 2-17.

Hair Jr, J. F. - Hult, G. T. - Ringle, C. - Sarstedt, M. (2016): A primer on partial least squares structural equation modeling (PLS-SEM). Thousand Oaks: Sage Publications

Hair, J. F. - Sarstedt, M. - Hopkins, L. - Kuppelwieser, $V$. G. (2014): Partial least squares structural equation modeling (PLS-SEM). An emerging tool in business research. European Business Review, 26(2), p. 106121. Letöltés dátuma: 2017. 10 20, forrás: https://www. researchgate.net/profile/Mei_Peng_Low/post/How_ can_a_reflective_construct_be_used_as_a_variable_ in a model/attachment/59d $\overline{\mathrm{d}} 6203 \mathrm{~d} 79197 \mathrm{~b} 80 \overline{7} 797 \mathrm{eb} 5 \overline{6} /$ A $\bar{S}:$ 289432935649281@1446017597272/download/Hai $\mathrm{r}+\mathrm{et}+\mathrm{al}+2014+\mathrm{PLS}+$ Business+Research.pdf

Hanges, P. - Dickson, M. W. (2004): The Development and Validation of the GLOBE Culture and Leadership Scales. In: R. House, P. Hanges, M. Javidan, P. Dorfman, - V. Gupta (szerk.): Culture, leadership, and organizations: The GLOBE study of 62 societies. Thousand Oaks: Sage, p. 122-151.

Hines, P. - Holweg, M. - Rich, N. (2004): Learning to evolve: a review of contemporary lean thinking. International Journal of Operations - Production Management, 24(10), p. 994-1011. doi:10.1108/01443570410558049

Hofmeister Tóth, Á. - Kopfer-Rácz, K. - Sas, D. (2015): A magyar kis- és közepes vállalkozások vezetőinek vállalkozói hajlandósága. Vezetéstudomány/Budapest Management Review, 46(7), p. 41-51.

Holweg, M. (2007): The genealogy of lean production. Journal of Operations Management, 25(2), p. 420-437. doi:10.1016/j.jom.2006.04.001

Hortoványi, L. (2010): Vállalkozó vezetés Magyarországon. Vezetéstudomány/Budapest Management Review, 41(4), p. 21-31.

Karácsonyi, A. (2006): A leadership, a szervezeti kultúra és kapcsolatuk jellegzetességei a magyar szervezetek esetében. Budapest: Budapesti Corvinus Egyetem. Forrás: http://phd.lib.uni-corvinus.hu/7/1/karacsonyi andras.pdf

Kovács, E. (2011): Pénzügyi adatok statisztikai elemzése. Budapest: BCE Pénzügyi és Számviteli Intézet. Tanszék Kft.

Kovács, Z. (2004): A korszerű termelési rendszerek sajátosságai. Harvard Business Manager, 6(4), p. 62-69.

Kovács, Z. - Rendesi, I. (2015): A lean projektek hatásai. Vezetéstudomány, 46(2), p. 15-24.

Laohavichien, T. - Fredendall, L. D. - Cantrell, S. R. (2011): Leadership and quality management practices in Thailand. International Journal of Operations - Production Management, 31(10), p. 1048-1070. doi:10.1108/01443571111172426
Liker, J. K. (2004): The Toyota Way. 14 Management Principles from the world's Greatest Manufacturer. New York, NY: McGraw-Hill

Liker, J. K. - Convis, G. L. (2012): The Toyota Way to Lean Leadership. Achieving and sustaining excellence through leadership development. New York: McGraw-Hill

Liker, J. K. - Hoseus, M. (2008): Toyota Culture: The Heart and Soul of the Toyota Way. New York: McGraw-Hill

Linting, M. - Meulman, J. J. - Groenen, P. J. - van der Koojj, A. J. (2007): Nonlinear principal components analysis: introduction and application. Psychological Methods, 12(3), p. 336. Forrás: http://psych.colorado. edu/ willcutt/pdfs/linting_2007.pdf

Lippert, R. - Gaál, Z. - Kovács, T. (2015): A vezetői szerepek és a szervezeti kultúra hatása a klasztersiker érettségi modelljére. Vezetéstudomány/Budapest Management Review, 46(8), p. 2-13.

Losonci, D. - Borsos, J. (2015): A lean menedzsment és a vállalati versenyképesség kapcsolata. Vezetéstudomány, 46(7), p. 52-62. Forrás: http://unipub.lib.unicorvinus.hu/2061/

Losonci, D. - Borsos, J. (2015): A lean menedzsment és a vállalati versenyképesség kapcsolata. Vezetéstudomány/Budapest Management Review, 46(7), p. 52-62.

Losonci, D. - Kása, R. - Szántó, R. - Zoltayné, P. (2018): Ügyvezetők és termelésvezetők lean termelési környezetben: vezetői képességek és vezetői módszerek. Vezetéstudomány, 49(2), p. 12-26. doi:10.14267/VEZTUD.2018.02.02

Lowe, J. (1993): Manufacturing reform and the changing role of the production supervisor: the case of the automobile industry. Journal of Management Studies, 30(5), p. 739-758. doi:10.1111/j.1467-6486.1993. tb00324.x

Monecke, A. - Leisch, F. (2012): semPLS: structural equation modeling using partial least squares. Journal of Statistical Software, 48(3), p. 1-32.

Nagy, G. - Berács, J. (2012): A hazai kis- és középvállalatok teljesítményét befolyásoló stratégiai orientációk (The effect of strategic orientations on the performance of Hungarian SMEs). Vezetéstudomány/Budapest Management Review, 42(2. kül), p. 46-56.

Netland, T. (2013): Exploring the phenomenon of company-specific production systems. International Journal of Production Research, 51(4), p. 1084-1097. doi:10 $.1080 / 00207543.2012 .676686$

Ohno, T. (1988): Toyota Production System: Beyond Large-Scale Production. Portland, OR: Productivity Press

Peng, D. X. - Lai, F. (2012): Using partial least squares in operations management research: A practical guideline and summary of past research. Journal of Operations Management, 30(6), p. 467-480. Letöltés dátuma: 2017. 10 20, forrás: https://www.cba.uh.edu/doctoral/ scm/docs/Peng-2012.pdf

Peng, D. X. - Lai, F. (2012): Using partial least squares in operations management research: A practical guideline and summary of past research. Journal of Operations Management, 30(6), p. 467-480. Forrás: https:// www.cba.uh.edu/doctoral/scm/docs/Peng-2012.pdf 
Pokinska, B. - Swartling, D. - Drotz, E. (2013): The daily work of Lean leaders - lessons from manufacturing and healthcare. Total Quality Management and Business Excellence, 24(7-8), p. 886-898 . doi:10.1080/1478 3363.2013 .791098

Seidel, A. - Saurin, T. - Marodin, G. - Ribeiro, J. (2017): Lean leadership competencies: a multi-method study. Management Decision, 55(10), p. 2163-2180. doi:10.1108/MD-01-2017-004

Shah, R. - Ward, P. T. (2003): Lean manufacturing: context, practice, and performance. Journal of Operations Management, 21(2), p. 12-149. doi:10.1016/S02726963(02)00108-0

Shah, R. - Ward, P. T. (2007): Defining and developing measures of lean production. Journal of Operations Management, 25(4), p. 785-805. doi:10.1016/j. jom.2007.01.019

Spear, S. J. (2004): Learning to lead at Toyota. Harvard Business Review, 82(5), p. 78-91.

Takács, S. - Németh, M. - Klér, J. A. - Toarniczky, A. (2017): Az egyetem melletti munkavégzés segítő és gátló tényezői diákszemmel-kérdőíves felmérés a BCE, BGE és BME mesterszakos hallgatói körében. Vezetéstudomány/Budapest Management Review, 48(3), p. 39-55.

Topár, J. (2009): A TQM vezetési filozófia és a minőségorientált vezetési rendszerek. Vezetéstudomány, 40(különszám), p. 85-90. Forrás: http://unipub.lib.unicorvinus.hu/3019/

Tortorella, G. - Fogliatto, F. (2017): Implementation of lean manufacturing and situational leadership styles: An empirical study. Leadership - Organization Deve- lopment Journal, 38(7), p. 946-968. doi:10.1108/LODJ07-2016-0165

Tortorella, G. - Fettermann, D. - Anzanello, M. - Sawh$n e y, R$. (2017): Lean manufacturing implementation, context and behaviors of multi-level leadership: A mixed-methods exploratory research. Journal of Manufacturing Technology Management, 28(7), p. 867-891. doi:10.1108/JMTM-06-2017-0128

van Dun, D. H. - Wilderom, C. P. (2016): Lean-team effectiveness through leader values and members' informing. International Journal of Operations - Production Management, 36(11), p. 1530 - 1550.

van Dun, D. H. - Hicks, J. N. - Wilderom, C. P. (2017): Values and behaviors of effective lean managers: Mixed-methods exploratory research. European Management Journal, 35(2), p. 174-186. doi:10.1016/j. emj.2016.05.001

Wilkinson, B. - Gamble, J. - Humphrey, J. - Morris, J. Anthony, D. (2001): The new international division of labour in Asian electronics: work organization and human resources in Japan and Malaysia. Journal of Management Studies, 38(5), p. 675-695. doi:10.1111/14676486.00254

Womack, J. - Jones, D. (1996): Lean Thinking. Banish Waste and Create Wealth in Your Corporation. New York, NY: Simon - Schuster

Zarinah, A. - Farhana, A. N. - Nadiah, A. (2017): Lean production and business performance: influences of leadership styles. Journal of Fundamental and Applied Sciences, 9(5S), p. 1030-1051. doi:10.4314/jfas. v9i5s.71

\section{1. melléklet A GLOBE leadership jegyek - nemzetközi és hazai kutatások}

Megjegyzés: a változók értékelése: I= Ez a viselkedés vagy tulajdonság "nagymértékben gátolja", hogy valaki kiváló vezetö legyen, $2=$ Ez a viselkedés vagy tulajdonság "némiképpen gátolja", hogy valaki kiváló vezetö legyen, $3=$ Ez a viselkedés vagy tulajdonság "kismértékben, de gátolja", hogy valaki kiváló vezetö legyen, $4=$ Ez a viselkedés vagy tulajdonság "nincs hatással" arra, hogy valaki kiváló vezetö legyen, $5=E z$ a viselkedés vagy tulajdonság "kismértékben hozzásegit", hogy valaki kiváló vezetö legyen, $6=$ Ez a viselkedés vagy tulajdonság "némiképpen hozzásegit", hogy valaki kiváló vezetö legyen, $7=$ Ez a viselkedés vagy tulajdonság "nagymértékben hozzásegit", hogy valaki kiváló vezetö legyen

Árnyalatok magyarázata: fekete - pozitív hatással van a lean termelési technikák használatára, szürke - negatív hatással van a lean termelési technikák használatára 


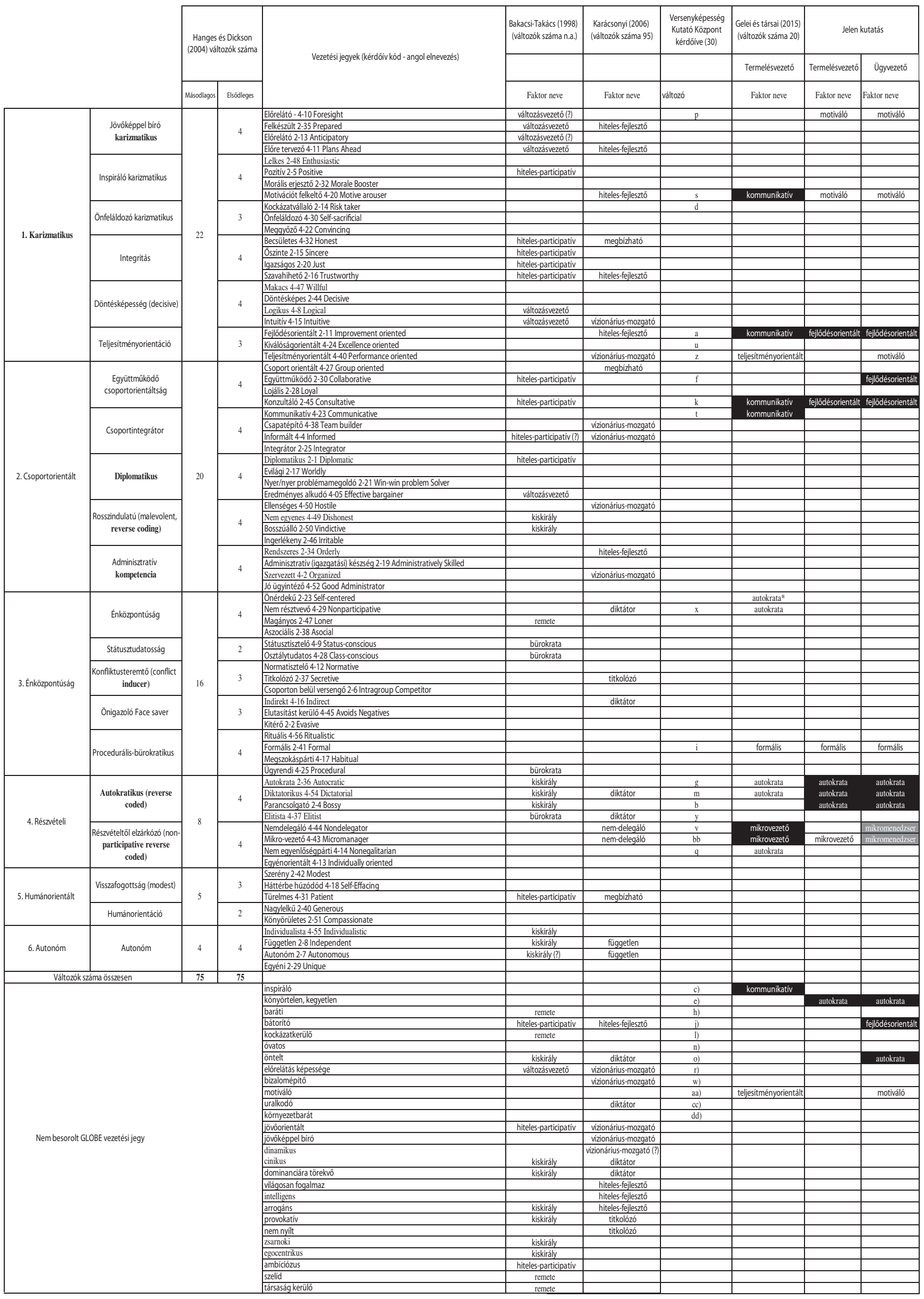


2. melléklet A két vezetői szinten képzett faktorokat alkotott változók négyzetes loading értékei

\begin{tabular}{|c|c|c|}
\hline Adatbázis & Változó & $\begin{array}{l}\text { Négyzetes } \\
\text { loading }\end{array}$ \\
\hline \multirow{15}{*}{ Ügyvezető } & Parancsolgató & $59,29 \%$ \\
\hline & $\begin{array}{l}\text { Könyörtelen, } \\
\text { kegyetlen }\end{array}$ & $59,29 \%$ \\
\hline & Autokrata & $53,29 \%$ \\
\hline & Diktatórikus & $64,00 \%$ \\
\hline & Öntelt & $49,00 \%$ \\
\hline & Formális & $100,00 \%$ \\
\hline & Fejlődésorientált & $50,41 \%$ \\
\hline & Együttmüködő & $24,01 \%$ \\
\hline & Bátorító & $67,24 \%$ \\
\hline & Konzultáló & $62,41 \%$ \\
\hline & Mikrovezetö & $56,25 \%$ \\
\hline & Nem delegáló & $88,36 \%$ \\
\hline & Motiváló & $53,29 \%$ \\
\hline & Előrelátó & $65,61 \%$ \\
\hline & Teljesítményorientált & $67,24 \%$ \\
\hline \multirow{10}{*}{$\begin{array}{c}\text { Termelés- } \\
\text { vezető }\end{array}$} & Parancsolgató & $53,29 \%$ \\
\hline & $\begin{array}{c}\text { Könyörtelen, } \\
\text { kegyetlen }\end{array}$ & $51,84 \%$ \\
\hline & Autokrata & $65,61 \%$ \\
\hline & Diktatórikus & $67,24 \%$ \\
\hline & Fejlődésorientált & $82,81 \%$ \\
\hline & Konzultáló & $54,76 \%$ \\
\hline & Formális & $100,00 \%$ \\
\hline & Mikrovezető & $100,00 \%$ \\
\hline & Motiváló & $86,49 \%$ \\
\hline & Előrelátó & $62,41 \%$ \\
\hline
\end{tabular}

3. melléklet $A$ különböző vezetői szinteken képzett faktorok kommunalitásai

\begin{tabular}{|c|c|c|}
\hline Adatbázis & Faktor & Kommunalitás \\
\hline Ügyvezető & Autokrata & $57,0 \%$ \\
& Formális & $\cdot$ \\
& Fejlődésorientált & $60,0 \%$ \\
& Mikrovezető & $53,3 \%$ \\
& Motiváló & $63,0 \%$ \\
\hline Termelésvezető & Autokrata & $59,0 \%$ \\
& Fejlődésorientált & $69,0 \%$ \\
& Formális & $\cdot$ \\
& Mikrovezető & $\cdot$ \\
& Motiváló & $75,0 \%$ \\
\hline
\end{tabular}

\section{4. melléklet $A$ vizsgált vezetői szinteken képzett} faktorok, és az őket alkotó változók loadingjai

\begin{tabular}{|c|c|c|c|c|c|}
\hline \multicolumn{6}{|l|}{ Ügyvezetö } \\
\hline & Autokrata & Formalis & FejlOrient & MikroMan & Motivalo \\
\hline $\begin{array}{l}\text { Parancsol- } \\
\text { gató }\end{array}$ & 0,77 & . & . & . & . \\
\hline $\begin{array}{c}\text { Könyörtelen, } \\
\text { kegyetlen }\end{array}$ & 0,77 & . & . & . & . \\
\hline Autokrata & 0,73 & . & . & . & . \\
\hline Diktatórikus & 0,80 & . & . & . & . \\
\hline Öntelt & 0,70 & . & . & . & . \\
\hline Formális & . & 1 & . & . & . \\
\hline $\begin{array}{l}\text { Fejlödés- } \\
\text { orientált }\end{array}$ & . & . & 0,71 & . & . \\
\hline Bátorító & . & . & 0,82 & . & . \\
\hline Konzultáló &. & . & 0,79 & . & . \\
\hline Mikrovezető & . & . & . & 0,75 & . \\
\hline $\begin{array}{c}\text { Nem } \\
\text { delegáló }\end{array}$ & . & . & . & 0,94 & . \\
\hline Motiváló & . & . & . & . & 0,73 \\
\hline Előrelátó & . & . &. & . & 0,81 \\
\hline M13Z & . & . & . & . & 0,82 \\
\hline \multicolumn{6}{|l|}{$\begin{array}{c}\text { Teljesítmény- } \\
\text { orientált }\end{array}$} \\
\hline & Autokrata & $\begin{array}{c}\text { FejlOri- } \\
\text { ent }\end{array}$ & Formalis & Mikroman & Motivalo \\
\hline $\begin{array}{c}\text { Parancsol- } \\
\text { gató }\end{array}$ & 0,73 & . & . & . & . \\
\hline $\begin{array}{c}\text { Könyörtelen, } \\
\text { kegyetlen }\end{array}$ & 0,72 & . & . & . & . \\
\hline Autokrata & 0,81 & . & . & . & . \\
\hline Diktatórikus & 0,82 & . & . & . & . \\
\hline $\begin{array}{c}\text { Fejlödés- } \\
\text { orientált }\end{array}$ & . & 0,91 & . & . & . \\
\hline Konzultáló & . & 0,74 & . & . & . \\
\hline Formális & . & . & 1 & . & . \\
\hline Mikrovezeto" & . & . & . & 1 & . \\
\hline Motiváló & . & . & . & . & 0,93 \\
\hline Előrelátó & . & . & . & . & 0,79 \\
\hline
\end{tabular}


5. melléklet Faktorok háromdimenziós térbe történő leskálázásának eredményei $\triangle$

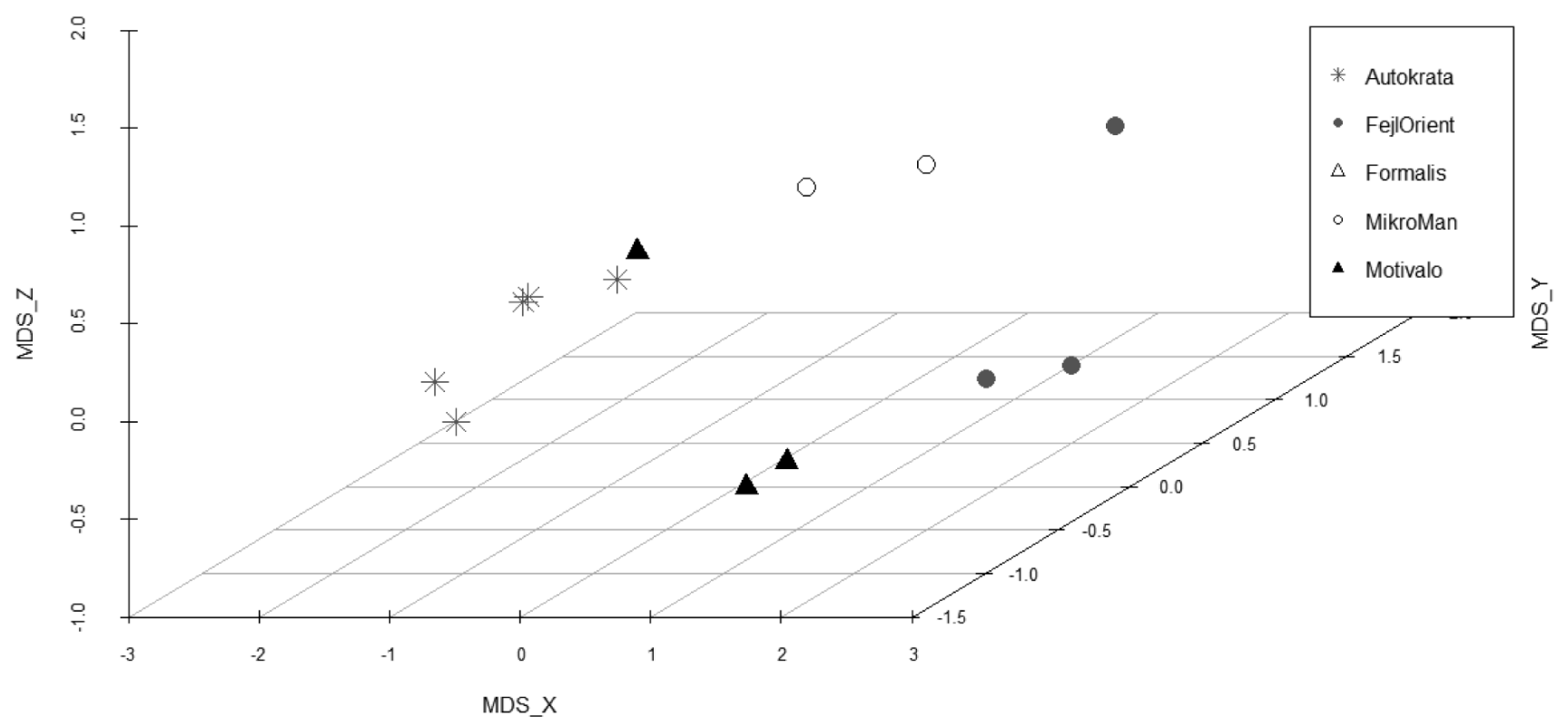

